\title{
Insight into global trends in aerosol composition from 2005 to 2015 inferred from the OMI Ultraviolet Aerosol Index
}

\author{
Melanie S. Hammer ${ }^{1}$, Randall V. Martin ${ }^{1,2}, \mathrm{Chi} \mathrm{Li}^{1}$, Omar Torres $^{3}$, Max Manning $^{1}$, and Brian L. Boys ${ }^{1}$ \\ ${ }^{1}$ Department of Physics and Atmospheric Science, Dalhousie University, Halifax, Nova Scotia, Canada \\ ${ }^{2}$ Harvard-Smithsonian Center for Astrophysics, Cambridge, MA, USA \\ ${ }^{3}$ Atmospheric Chemistry and Dynamics Laboratory, NASA Goddard Space Flight Center, Greenbelt, MD, USA
}

Correspondence: Melanie S. Hammer (melanie.hammer@dal.ca)

Received: 14 December 2017 - Discussion started: 12 February 2018

Revised: 24 May 2018 - Accepted: 25 May 2018 - Published: 8 June 2018

\begin{abstract}
Observations of aerosol scattering and absorption offer valuable information about aerosol composition. We apply a simulation of the Ultraviolet Aerosol Index (UVAI), a method of detecting aerosol absorption from satellite observations, to interpret UVAI values observed by the Ozone Monitoring Instrument (OMI) from 2005 to 2015 to understand global trends in aerosol composition. We conduct our simulation using the vector radiative transfer model VLIDORT with aerosol fields from the global chemical transport model GEOS-Chem. We examine the 2005-2015 trends in individual aerosol species from GEOS-Chem and apply these trends to the UVAI simulation to calculate the change in simulated UVAI due to the trends in individual aerosol species. We find that global trends in the UVAI are largely explained by trends in absorption by mineral dust, absorption by brown carbon, and scattering by secondary inorganic aerosol. Trends in absorption by mineral dust dominate the simulated UVAI trends over North Africa, the Middle East, East Asia, and Australia. The UVAI simulation resolves observed negative UVAI trends well over Australia, but underestimates positive UVAI trends over North Africa and Central Asia near the Aral Sea and underestimates negative UVAI trends over East Asia. We find evidence of an increasing dust source from the desiccating Aral Sea that may not be well represented by the current generation of models. Trends in absorption by brown carbon dominate the simulated UVAI trends over biomass burning regions. The UVAI simulation reproduces observed negative trends over central South America and West Africa, but underestimates observed UVAI trends over boreal forests. Trends in scattering by secondary inorganic aerosol dominate the simu-
\end{abstract}

lated UVAI trends over the eastern United States and eastern India. The UVAI simulation slightly overestimates the observed positive UVAI trends over the eastern United States and underestimates the observed negative UVAI trends over India. Quantitative simulation of the OMI UVAI offers new insight into global trends in aerosol composition.

\section{Introduction}

Atmospheric aerosols have significant climate impacts due to their ability to scatter and absorb solar radiation and to their indirect effect through modification of cloud properties. The exact magnitude of the direct radiative forcing remains highly uncertain (IPCC, 2014), although most studies agree it is significant (Andreae and Gelencsér, 2006; Mann and Emanuel, 2006; Mauritsen, 2016). Storelvmo et al. (2016) estimate that changes in global aerosol loading over the past 45 years have caused cooling (direct and indirect) that masks about one-third of the atmospheric warming due to increasing greenhouse gas emissions. Aerosol absorption has been estimated to be the second-largest source of atmospheric warming after carbon dioxide (Ramanathan and Carmichael, 2008; Bond et al., 2013; IPCC, 2014), although considerable uncertainty remains regarding the exact magnitude (Stier et al., 2007). The large uncertainty regarding the direct radiative impacts of aerosols on climate is driven by the large variability in aerosol physical and chemical properties, as well as their various emission sources, making it extremely difficult to fully understand their interactions with radiation (Pöschl, 2005; Moosmüller et al., 2009; Curci et al., 2015; Kristiansen 
et al., 2016). Global observations of trends in aerosol scattering and absorption would offer valuable constraints on trends in aerosol sources and composition.

The emissions of aerosols and their precursors have changed significantly over the past decade. In North America and Europe, the anthropogenic emissions of most aerosol species (e.g. black carbon, organic aerosols) and aerosol precursors (e.g. sulfur dioxide and nitrogen oxides) have decreased due to pollution controls (Leibensperger et al., 2012; Klimont et al., 2013; Curier et al., 2014; Simon et al., 2015; Xing et al., 2015; C. Li et al., 2017). By contrast, emissions of aerosols and aerosol precursors have increased in developing countries due to increased industrial activity, particularly in China and India. Chinese emissions of black carbon $(\mathrm{BC})$, organic carbon $(\mathrm{OC})$, and nitrogen oxides $\left(\mathrm{NO}_{x}\right)$ have been increasing over the past decade (Zhao et al., 2013; Cui et al., 2015), although in the most recent years $\mathrm{NO}_{x}$ emissions have been declining, driven by denitration devices at power plants (Liu et al., 2016). Due to the wide implementation of flue-gas desulfurization equipment in most power plants in China, emissions of sulfur dioxide $\left(\mathrm{SO}_{2}\right)$ in some regions have been decreasing since about 2006-2008 (Lu et al., 2011; Wang et al., 2015; Fioletov et al., 2016). Indian emissions of anthropogenic aerosols and their precursors have been increasing over the past decade ( $\mathrm{Lu}$ et al., 2011; Klimont et al., 2017). There have also been significant changes in global dust and biomass burning emissions. Shao et al. (2013) use synoptic data to estimate a global decrease in dust emissions between 1974 and 2012, driven largely by reductions from North Africa with weaker contributions from Northeast Asia, South America, and South Africa. By examining trends in burned area, Giglio et al. (2013) estimate a decrease in global biomass burning emissions between 2000 and 2012. Trends in aerosol composition produced by these changing emissions may be detectable from satellite observations of aerosol scattering and absorption.

Detection of aerosol composition from passive nadir satellite observations is exceedingly difficult; few methods exist. The aerosol-type classification provided by retrievals from the MISR instrument, enabled by multi-angle viewing, is one such source of information about aerosol composition from constraints on particle size, shape, and single scattering albedo (SSA) (Kahn and Gaitley, 2015). MISR retrievals have been used to classify particles relating to events such as biomass burning, desert dust, volcanic eruptions, and pollution events (e.g. Liu et al., 2007; Kalashnikova and Kahn, 2008; Dey and Di Girolamo, 2011; Scollo et al., 2012; Guo et al., 2013). The most commonly used satellite product for aerosol information is aerosol optical depth (AOD), the columnar extinction of radiation by atmospheric aerosols. AOD can be retrieved from satellite measurements of topof-atmosphere (TOA) radiance in combination with prior knowledge of aerosol optical properties. Several studies have examined trends in satellite AOD. Following trends in emissions, over the past decade positive trends in satellite AOD have been observed over Asia and Africa, corresponding to regions experiencing industrial growth (de Meij et al., 2012; Chin et al., 2014; Mao et al., 2014; Mehta et al., 2016), while negative trends in satellite AOD have been observed over North America and Europe, largely due to pollution controls (Hsu et al., 2012; de Meij et al., 2012; Chin et al., 2014; Mehta et al., 2016). Studies such as these demonstrate the information about the evolution of aerosol abundance offered by total column AOD retrievals, but measurements of absorption would complement the scattering information in AOD retrievals by providing independent information on aerosol composition.

The Ultraviolet Aerosol Index (UVAI) is a method of detecting aerosol absorption from satellite-measured radiances (Herman et al., 1997; Torres et al., 1998). Because the UVAI is calculated from measured radiances, a priori assumptions about aerosol composition are not required for its calculation, thus yielding independent information on aerosol scattering (Herman et al., 1997; Torres et al., 1998, 2007; de Graaf et al., 2005; Penning de Vries et al., 2009) and absorption. The UVAI has been widely applied to examine mineral dust (Israelevich et al., 2002; Schepanski et al., 2007; Badarinath et al., 2010; Huang et al., 2010) and biomass burning aerosols (Duncan et al., 2003; Guan et al., 2010; Torres et al., 2010; Kaskaoutis et al., 2011; Mielonen et al., 2012), including brown carbon (BrC) (Jethva and Torres, 2011; Hammer et al., 2016). The UVAI is not typically used to examine scattering aerosol, but aerosol scattering causes a net decrease in the overall value of the UVAI, meaning that the UVAI could be used to detect changes due to both aerosol absorption and scattering. Prior interpretation of the UVAI has been complicated by its dependence on geophysical parameters, such as aerosol layer height (Herman et al., 1997; Torres et al., 1998; de Graaf et al., 2005). Examining trends in the UVAI would provide an exciting opportunity to investigate the evolution of aerosol absorption and scattering over time, if the multiple parameters affecting the UVAI could be accounted for through simulation.

In this work, we apply a simulation of the UVAI, which was developed and evaluated regionally and seasonally in Hammer et al. (2016), to interpret trends in recently reprocessed Ozone Monitoring Instrument (OMI) UVAI observations for 2005-2015 to understand global changes in aerosol composition. We interpret observed UVAI values by using a radiative transfer model (VLIDORT) to calculate UVAI values as a function of simulated aerosol composition from the global 3-D chemical transport model GEOS-Chem. By using scene-dependent OMI viewing geometry together with scene-dependent modelled atmospheric composition we enable quantitative comparison of model results with observations. Comparison of trends in observed OMI UVAI values to the trends in simulated UVAI values, which are calculated using known aerosol composition, enables qualification of how changes in aerosol absorption and scattering could influence the observed UVAI trends and identification of model devel- 
opment needs. We conduct our analysis at the global scale to understand trends worldwide. Section 2 describes the OMI UVAI observations and our UVAI simulation. Section 3 examines the trends in emissions of GEOS-Chem aerosols and their precursors for 2005-2015 to provide context for the trends in our simulated UVAI. Section 4 compares the mean values during 2005-2015 of the OMI UVAI and our simulated UVAI. Section 5 compares the 2005-2015 trends in OMI and simulated UVAI values. In Sect. 6 we examine the sensitivity of the UVAI to changes in the abundance of individual aerosol species. Trends in our UVAI simulation are interpreted by applying the trends in the GEOS-Chem aerosol species to calculate the associated change in UVAI. Section 7 reports the conclusions.

\section{Methods}

\subsection{OMI Ultraviolet Aerosol Index}

The OMI UVAI is a method of detecting absorbing aerosols from satellite measurements in the near-UV wavelength region and is a product of the OMI near-UV algorithm (OMAERUV) (Herman et al., 1997; Torres et al., 1998, 2007). The OMAERUV algorithm uses the 354 and $388 \mathrm{~nm}$ radiances measured by OMI to calculate the UVAI as a measure of the deviation from a purely Rayleigh scattering atmosphere bounded by a Lambertian reflecting surface. Positive UVAI values indicate absorbing aerosol while negative values indicate non-absorbing aerosol. Near-zero values occur when clouds and Rayleigh scattering dominate. Negative UVAI values due to aerosol scattering are often weak and have historically been affected by noise in previous datasets (Torres et al., 2007; Penning de Vries et al., 2015). Because UVAI values are calculated from TOA radiance which contains total aerosol effects, the presence (or absence) of scattering aerosol along with absorbing aerosol can either weaken (or strengthen) the absorption signal. Therefore the UVAI could be used to detect changes over time due to both aerosol absorption and scattering.

The main source of error affecting a trend analysis of the UVAI is the OMI row anomaly, which has reduced the sensor viewing capability for specific scan angles since 2008 (http://projects.knmi.nl/omi/research/ product/rowanomaly-background.php, last access: $22 \mathrm{Au}-$ gust 2017). The sudden suppression of observations for specific viewing geometries (i.e. the row anomaly) could cause an additional spurious trend in the UVAI trend calculation. We address this concern by considering only scan positions $3-23$, which remain unaffected by the row anomaly, and also by using the recently reprocessed OMAERUV UVAI that is less sensitive to scan-angle-dependent cloud artifacts due to the implementation of a Mie-scattering-based water cloud model (Torres et al., 2018). We focus on cloud-filtered observations by excluding scenes with OMI UVAI radiative cloud fraction exceeding $5 \%$ to further reduce uncertainty due to clouds. Furthermore, we focus on 10 years of observations so that multiple observations can reduce the random error of UVAI observations.

Because the OMI UVAI is calculated directly from OMImeasured radiances, instrument degradation over time could be a significant source of uncertainty (Povey and Grainger, 2015). Schenkeveld et al. (2017) found that the OMI radiances in the channel used for the UVAI have changed by only $\sim 1-1.15 \%$ over the entire OMI record. Applying this change to the radiances results in a change in the absolute UVAI of $\sim 10^{-4}$, which is negligible. Schenkeveld et al. (2017) also calculated the trend in the ratio of the $354 / 380 \mathrm{~nm}$ radiances measured by OMI for pixels unaffected by the OMI row anomaly and over the tropical Pacific where the presence of aerosol is expected to be minimal, to assess the change in the spectral dependence of OMI's overall radiance calibration over the course of the mission. They found that the trend in the $354 / 380 \mathrm{~nm}$ radiance ratio over the entire OMI record was $<0.5 \%$ per decade. We estimate the effect of instrument degradation on our trend analysis by calculating the change in UVAI associated with the $0.5 \%$ per decade trend in the $354 / 380 \mathrm{~nm}$ radiance ratio. Applying the trend in $354 / 380 \mathrm{~nm}$ radiance ratio to the UVAI calculation globally resulted in a negligible change in the UVAI of $\sim 2 \times 10^{-4} \mathrm{yr}^{-1}$. To avoid the influence of any possible spurious trends due to instrument degradation on our trend analysis, we subtract the trend in global mean UVAI from the cloud-filtered UVAI prior to interpretation.

We perform trend analysis on monthly mean time series data for the years 2005-2015 using generalized least squares (GLS) regression, as described by Boys et al. (2014). Prior to regression, the data are aggregated to monthly mean values, and the monthly time series data are deseasonalized by subtracting the monthly mean for the period 2005-2015 to focus on the long-term trend. Deseasonalization is a recommended method to accurately calculate a long-term trend in a seasonally varying time series (Weatherhead et al., 1998, 2002; Wilks, 2011) and is widely employed for the trend analysis of geophysical data including temperature, chemical species concentrations, relative humidity, cloud cover, and aerosol parameters (Reynolds and Reynolds, 1988; Prinn et al., 1992; Pelletier and Turcotte, 1997; Zhang et al., 1997; Dai, 2006; Norris and Wild, 2007; Hsu et al., 2012; Boys et al., 2014; Li et al., 2014; Ma et al., 2016). Each pixel is required to have data for at least $60 \%$ of the time period before regression is performed. In the following section, we discuss our UVAI simulation and the implementation of the new UVAI algorithm in the simulation.

\subsection{Simulated UVAI}

We simulate the UVAI using the VLIDORT radiative transfer model (Spurr, 2006), following Buchard et al. (2015) and Hammer et al. (2016). We calculate the TOA radiances at 354 
and $388 \mathrm{~nm}$ needed for the UVAI calculation by supplying VLIDORT with the OMI viewing geometry for each scene, as well as the GEOS-Chem simulation of vertical profiles of aerosol extinction, spectrally dependent single scattering albedo, and the corresponding spectrally dependent scattering phase function. Thus these parameters account for the sensitivity of the UVAI to aerosol layer height and spectrally dependent aerosol optical properties.

We introduce to the UVAI simulation a Mie-scatteringbased water cloud model (Deirmendjian, 1964) for consistency with the reprocessed OMI UVAI dataset. Following Torres et al. (2018), we compute the radiances used in the UVAI calculation as a combination of clear and cloudy sky conditions. We use the same cloud fractions and cloud optical depths used in the OMI UVAI algorithm for coincident OMI pixels. We avoid cloudy scenes by considering only pixels with OMI radiative cloud fraction of less than $5 \%$. For the UVAI calculation we use the surface reflectance fields provided by OMI. We calculated the 2005-2015 trends in these surface reflectance fields and found that they were statistically insignificant globally and on the order of $10^{-5} \mathrm{yr}^{-1}$. We calculated the change in UVAI due to a change in surface reflectance of this order of magnitude and found that the change in UVAI was negligible. We also calculated the change in UVAI due to changes in simulated aerosol altitude, but found that the trends in aerosol altitude were negligible (order $10^{-5} \mathrm{hPa} \mathrm{yr}^{-1}$ ). Therefore we focus our analysis on trends in aerosol composition which have a larger effect on the UVAI as demonstrated below.

We use the GEOS-Chem model v11-01 (http://geos-chem. org, last access: 22 August 2017) as input to the UVAI simulation and to calculate the sensitivity of the UVAI simulation to aerosol composition. The simulation is driven by assimilated meteorological data from MERRA-2 Reanalysis of the NASA Global Modeling and Assimilation Office (GMAO). Our simulation is conducted at a spatial resolution of $2^{\circ} \times 2.5^{\circ}$ with 47 vertical levels for the years 2005-2015. We supply VLIDORT with GEOS-Chem aerosol fields coincident with OMI observations.

GEOS-Chem contains a detailed oxidant-aerosol chemical mechanism (Bey et al., 2001; Park et al., 2004). The aerosol simulation includes the sulfate-nitrate-ammonium system (Fountoukis and Nenes, 2007; Park et al., 2004; Pye et al., 2009), primary carbonaceous aerosol (Park et al., 2003), mineral dust (Fairlie et al., 2007), and sea salt (Jaeglé et al., 2011). Semivolatile primary organic carbon and secondary organic aerosol (SOA) formation is described in Pye et al. (2010). We update the original semi-volatile partitioning of SOA formed from isoprene with the irreversible uptake scheme in Marais et al. (2016). $\mathrm{HNO}_{3}$ concentrations are reduced following Heald et al. (2012). Aerosol optical properties are based on the Global Aerosol Data Set (GADS) (Koepke et al., 1997) as originally implemented by Martin et al. (2003), with updates for organics and secondary inorganics from aircraft observations (Drury et al., 2010), for mineral dust (Lee et al., 2009; Ridley et al., 2012), and for absorbing BrC (Hammer et al., 2016). Here we update the mineral dust optics at ultraviolet wavelengths using a refractive index that minimizes the difference between the mean simulated and OMI UVAI values to allow focus on trends. Aerosols are treated as externally mixed.

Anthropogenic emissions are from the EDGARv4.3.1 global inventory (Crippa et al., 2016) with emissions overwritten in areas with regional inventories for the United States (NEI11; Travis et al., 2016), Canada (CAC), Mexico (BRAVO; Kuhns et al., 2005), Europe (EMEP; http: //www.emep.int/, last access: 22 August 2017), China (MEIC v1.2; C. Li et al., 2017), and elsewhere in Asia (MIX; C. Li et al., 2017). Emissions from open fires for individual years from the GFED4 inventory (Giglio et al., 2013) are included. The long-term concentrations from this simulation have been extensively evaluated versus ground-based $\mathrm{PM}_{2.5}$ composition measurements where available and versus satellitederived $\mathrm{PM}_{2.5}$ trends (M. Li et al., 2017).

The Supplement evaluates trends in simulated $\mathrm{SO}_{2}, \mathrm{NO}_{2}$, and AOD versus satellite retrievals from multiple instruments and algorithms. We find broad consistency between our simulated $\mathrm{NO}_{2}$ and $\mathrm{SO}_{2}$ column trends with those from OMI (Supplement Figs. S1 and S2). Our simulated AOD trends are generally consistent with the trends in satellite AOD retrievals, with the exception of positive trends in AOD over western North America and near the Aral Sea in most retrieval products and a negative trend in AOD over Mongolia/Inner Mongolia in all retrieval products (Fig. S3).

We filter our GEOS-Chem aerosol simulated fields based on the coincident OMI pixels, which are regridded to the model resolution of $2^{\circ} \times 2.5^{\circ}$. This allows for the direct comparison between our GEOS-Chem simulation and the OMI UVAI observations.

\section{Trend in emissions of GEOS-Chem aerosols and their precursors}

Figure 1 shows the trends in emissions of aerosols and their precursors from our GEOS-Chem simulation calculated from the GLS regression of monthly time series values for 20052015. Cool colours indicate negative trend values, warm colours indicate positive trend values, and the opacity of the colours indicates the statistical significance of the trends. The trends in emissions of sulfur dioxide $\left(\mathrm{SO}_{2}\right)$ and nitrogen oxides $\left(\mathrm{NO}_{x}\right)$ follow similar patterns (Fig. 1a and b, respectively). Negative trends ( -1 to $-0.01 \mathrm{~kg} \mathrm{~km}^{-2} \mathrm{yr}^{-1}$ ) are present over North America and Europe, corresponding to pollution controls (Leibensperger et al., 2012; Klimont et al., 2013; Curier et al., 2014; Simon et al., 2015; Xing et al., 2015; C. Li et al., 2017). Positive trends (0.5 to $1 \mathrm{~kg} \mathrm{~km}^{-2} \mathrm{yr}^{-1}$ ) in both species are present over India and eastern China, but the positive trends in emissions of $\mathrm{SO}_{2}$ over eastern China are interspersed with negative trends $(-1$ 

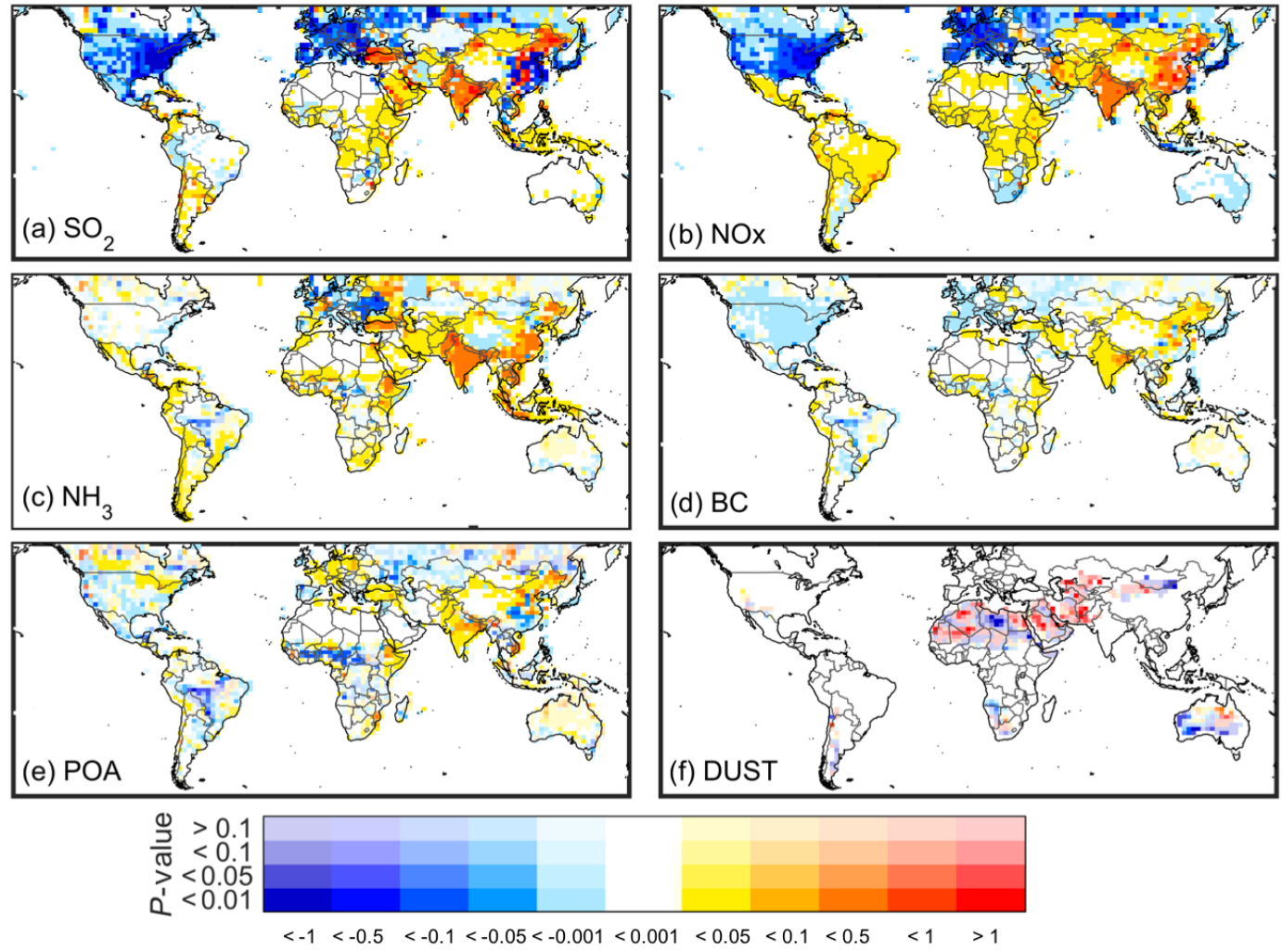

GEOS-Chem aerosol and precursor emission trends for 2005-2015 $\left(\mathrm{kg} \mathrm{km}^{-2} \mathrm{yr}^{-1}\right)$

Figure 1. Trend in emissions of (a) sulfur dioxide $\left(\mathrm{SO}_{2}\right)\left(\mathrm{kg} \mathrm{SO}_{2} \mathrm{~km}^{-2} \mathrm{yr}^{-1}\right)$, (b) nitrogen oxides $\left(\mathrm{NO}_{x}\right)\left(\mathrm{kg} \mathrm{NO} \mathrm{km}^{-2} \mathrm{yr}^{-1}\right)$, ammonia $\left(\mathrm{NH}_{3}\right)\left(\mathrm{kg} \mathrm{NH}_{3} \mathrm{~km}^{-2} \mathrm{yr}^{-1}\right)$, black carbon (BC) $\left(\mathrm{kg} \mathrm{C} \mathrm{km}^{-2} \mathrm{yr}^{-1}\right)$, primary organic carbon (POA) $\left(\mathrm{kgC} \mathrm{km}^{-2} \mathrm{yr}^{-1}\right)$, and dust $\left(\mathrm{kg} \mathrm{km}^{-2} \mathrm{yr}^{-1}\right)$ used in our GEOS-Chem simulation. The trends are calculated from the generalized least squares regression of monthly time series values during 2005-2015.

to $-0.5 \mathrm{~kg} \mathrm{~km}^{-2} \mathrm{yr}^{-1}$ ) in $\mathrm{SO}_{2}$ emissions, corresponding to the deployment of desulfurization equipment in power plants in recent years (Lu et al., 2011; Klimont et al., 2013; Wang et al., 2015). Ammonia $\left(\mathrm{NH}_{3}\right)$ emissions (Fig. 1c) have positive trends $\left(0.001\right.$ to $0.05 \mathrm{~kg} \mathrm{~km}^{-2} \mathrm{yr}^{-1}$ ) over most of South America, North Africa, the Middle East, and most of Asia with larger trends $\left(0.1\right.$ to $\left.0.5 \mathrm{~kg} \mathrm{~km}^{-2} \mathrm{yr}^{-1}\right)$ over India and eastern China. There are positive trends $(0.001$ to $0.05 \mathrm{~kg} \mathrm{~km}^{-2} \mathrm{yr}^{-1}$ ) in $\mathrm{BC}$ emissions (Fig. 1d) over North Africa, Europe, the Middle East, India, and China and negative trends $\left(-0.05\right.$ to $\left.-0.001 \mathrm{~kg} \mathrm{~km}^{-2} \mathrm{yr}^{-1}\right)$ over North America, Europe, West Africa, and central South America. The trends in primary organic aerosol (POA) emissions (Fig. 1e) follow a similar pattern as the trends in $\mathrm{BC}$ emissions, except there are negative trends $(-0.1$ to $-0.05 \mathrm{~kg} \mathrm{~km}^{-2} \mathrm{yr}^{-1}$ ) over eastern China and the negative trends ( -1 to $\left.-0.1 \mathrm{~kg} \mathrm{~km}^{-2} \mathrm{yr}^{-1}\right)$ over West Africa and central South America are larger in magnitude reflecting regional changes in fire activity (Chen et al., 2013; Andela and van der Werf, 2014). There are also positive trends ( 0.001 to $0.05 \mathrm{~kg} \mathrm{~km}^{-2} \mathrm{yr}^{-1}$ ) over the northern United States and Canada. The trends in dust emissions (Fig. 1f) show the largest magnitude of all the various species, although many have low statistical significance, with areas of positive and negative trends $\left(>1\right.$ and $\left.<-1 \mathrm{~kg} \mathrm{~km}^{-2} \mathrm{yr}^{-1}\right)$ over North Africa, positive trends $\left(>1 \mathrm{~kg} \mathrm{~km}^{-2} \mathrm{yr}^{-1}\right)$ parts of the Middle East, and negative trends $\left(<-1 \mathrm{~kg} \mathrm{~km}^{-2} \mathrm{yr}^{-1}\right)$ over northern China and southern Australia.

\section{Mean UVAI values for 2005-2015}

We examine the seasonal long-term mean UVAI values for insight into the spatial distribution of the aerosol absorption signals. Figures 2 and 3 show the seasonal mean UVAI values for 2005-2015 for OMI and the simulation, respectively. Positive UVAI values between 0.2 and 1.5 indicating aerosol absorption are present over major desert regions globally for both OMI and the simulation, particularly over the Saharan, Iranian, and Thar deserts. These positive signals are driven by the absorption by mineral dust (Herman et al., 1997; Torres et al., 1998; Buchard et al., 2015). The simulation underestimates some of the smaller dust features captured by OMI, such as over western North America, South America, Australia, and parts of Asia, perhaps reflecting an underesti- 

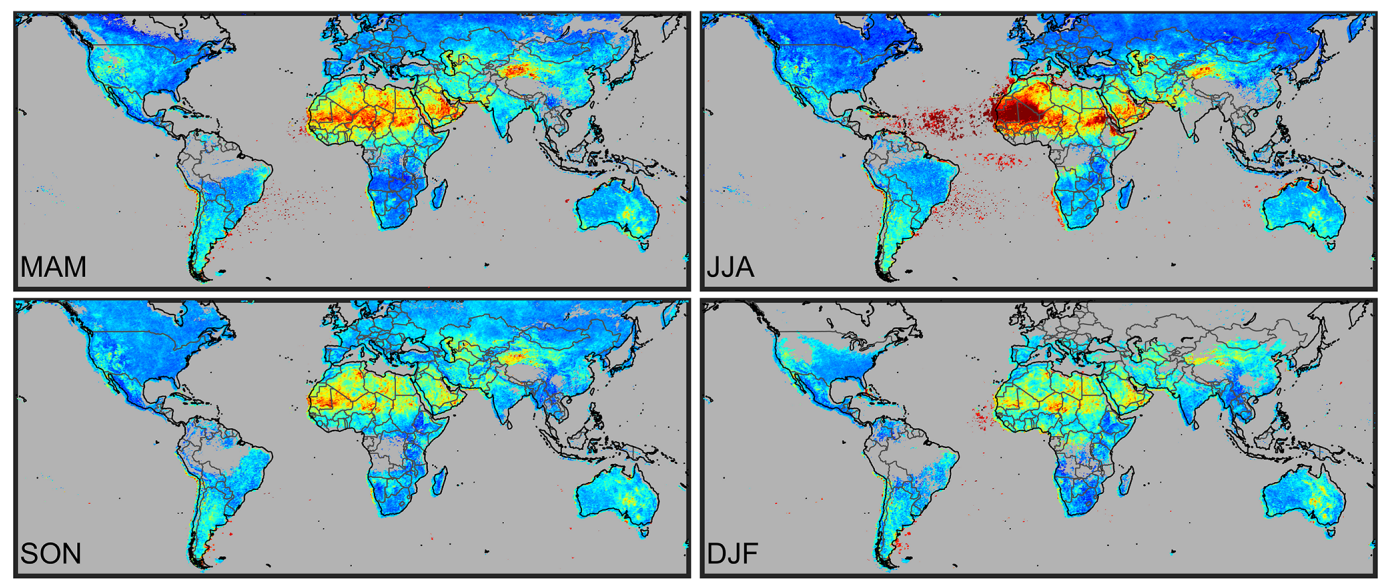

$-0.5$

$\begin{array}{ccc}0 & 0.5 & 1 \\ \text { UVAI seasonal mean for } & 2005-2015\left(\mathrm{yr}^{-1}\right)\end{array}$

Figure 2. Seasonal mean UVAI values for the 2005-2015 period as observed by OMI for MAM (May, April, March), JJA (June, July August), SON (September, October, November), and DJF (December, January, February). Grey indicates persistent cloud fraction greater than $5 \%$.
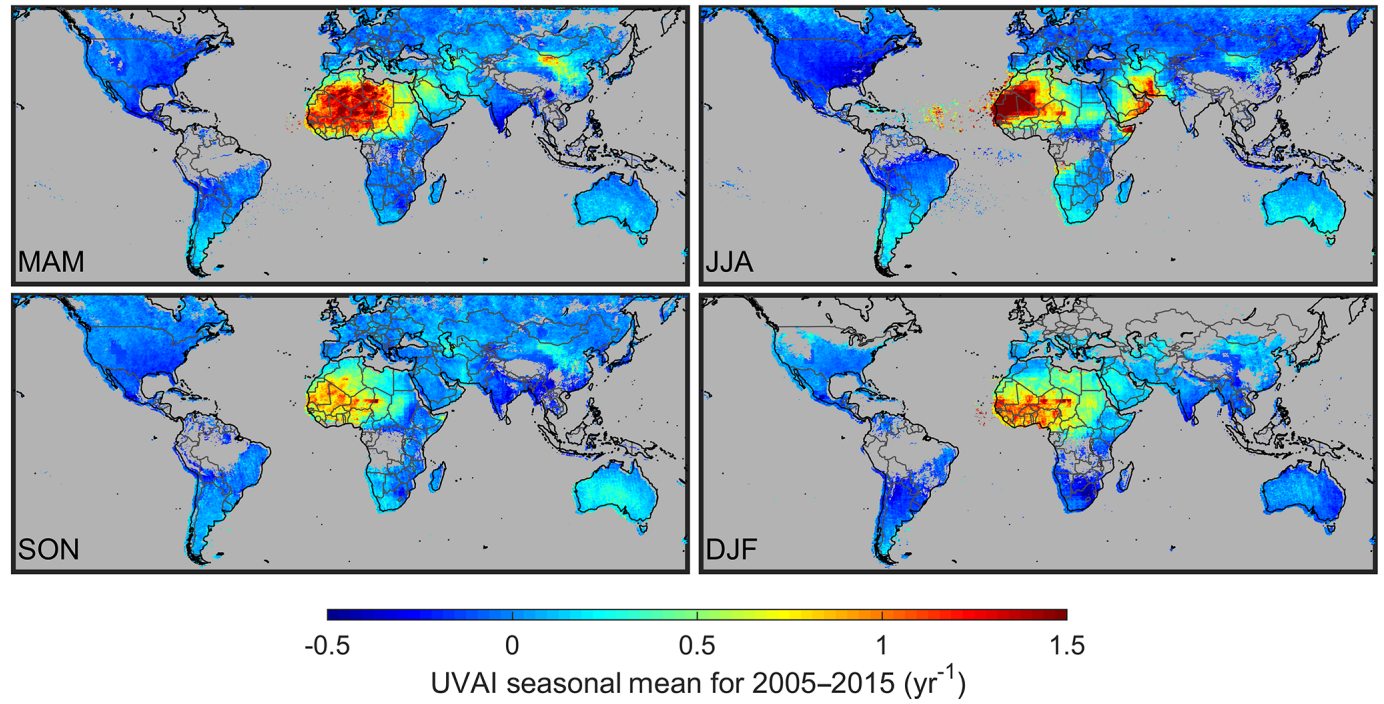

Figure 3. Seasonal mean UVAI values for the 2005-2015 period from our simulation coincidently sampled from OMI for MAM (May, April, March), JJA (June, July August), SON (September, October, November), and DJF (December, January, February). Grey indicates persistent cloud fraction greater than $5 \%$.

mation in the simulated mineral dust lifetime (Ridley et al., 2012) and missing dust sources (Ginoux et al., 2012; Guan et al., 2016; Huang et al., 2015; Philip et al., 2017). The seasonal variation in the observed and simulated UVAI is similar albeit with larger simulated values in spring (MAM) over North Africa. In all seasons, the UVAI values driven by absorption by dust in the simulation are concentrated mostly over North Africa, while for OMI the UVAI values are more homogeneous over the Middle East and Asia as well. Positive UVAI values of $\sim 0.2-1$ over West and Central Africa appearing in both the OMI and simulated values correspond to absorption by $\mathrm{BrC}$ from biomass burning activities in these regions (Jethva and Torres, 2011; Hammer et al., 2016). Over ocean most data are removed by our strict cloud filter.

\section{Trend in UVAI values between 2005 and 2015}

Figure 4 shows the trend in OMI and simulated UVAI values (coincidently sampled from OMI) calculated from the GLS regression of monthly UVAI time series values during 2005-2015. Several regions exhibit consistency between 


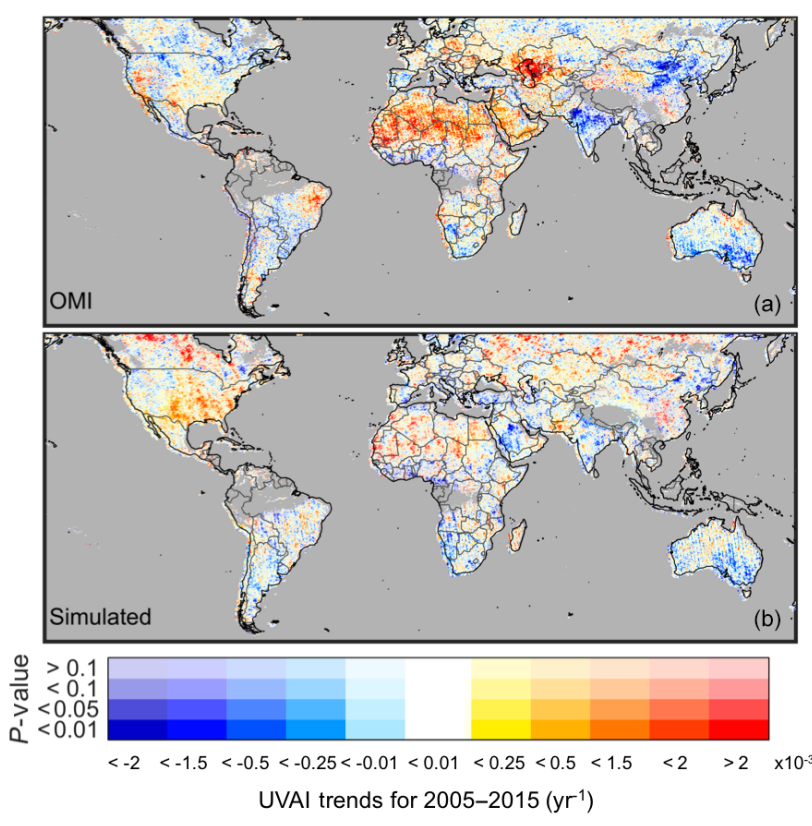

Figure 4. Trends in OMI (a) and simulated (b) UVAI values coincidently sampled from OMI calculated from the generalized least squares regression of monthly time series values during 2005-2015. The opacity of the colours indicates the statistical significance of the trend. Grey indicates persistent cloud fraction greater than $5 \%$.

the OMI and simulated UVAI trends. There are statistically significant positive trends in both OMI and simulated UVAI values over the eastern United States (OMI: $1.0 \times 10^{-5}$ to $2.5 \times 10^{-4} \mathrm{yr}^{-1}$; simulated: $2.5 \times 10^{-4}$ to $\left.5.0 \times 10^{-4} \mathrm{yr}^{-1}\right)$ and Canada and parts of Russia (OMI: $1.0 \times 10^{-5}$ to $2.5 \times 10^{-4} \mathrm{yr}^{-1}$; simulated: $5.0 \times 10^{-4}$ to $2.0 \times 10^{-3} \mathrm{yr}^{-1}$ ).

Positive UVAI trends $\left(1.0 \times 10^{-5}\right.$ to $\left.2.5 \times 10^{-4} \mathrm{yr}^{-1}\right)$ in both OMI and simulated values are present over Europe, although the simulated trends have low statistical significance. Statistically significant positive UVAI trends $\left(5.0 \times 10^{-4}\right.$ to $\left.2.0 \times 10^{-3} \mathrm{yr}^{-1}\right)$ in OMI values are apparent over North Africa, which generally are captured by the simulation but with low statistical significance. Negative UVAI trends $\left(-1.5 \times 10^{-3}\right.$ to $\left.-1.0 \times 10^{-5} \mathrm{yr}^{-1}\right)$ in both OMI and simulated values are apparent over most of South America, southern Africa, and Australia. Negative UVAI trends $\left(-2 \times 10^{-3}\right.$ to $-5.0 \times 10^{-4} \mathrm{yr}^{-1}$ ) in both OMI and simulated values are present over West Africa, with low statistical significance that could be related to the filtering of persistent clouds. OMI and simulated UVAI values show negative trends $\left(-2 \times 10^{-3}\right.$ to $\left.-5 . \times 10^{-4} \mathrm{yr}^{-1}\right)$ over India, although the simulated trends have lower statistical significance.

Some regions have trends in OMI UVAI values which are not captured by the simulation. Statistically significant positive UVAI trends $\left(2.5 \times 10^{-4}\right.$ to $\left.1.5 \times 10^{-3} \mathrm{yr}^{-1}\right)$ over the western United States are apparent in the OMI values but not in the simulation. Zhang et al. (2017) found positive trends in aerosol absorption optical depth from OMI retrievals that they attributed to positive trends in mineral dust over the region, which were not captured by their GEOS-Chem simulation. Statistically significant positive UVAI trends $\left(5.0 \times 10^{-4}\right.$ to $\left.2.0 \times 10^{-3} \mathrm{yr}^{-1}\right)$ in OMI values exist over the Middle East, while the simulation has negative trends with low statistical significance. The OMI UVAI reveals a region of statistically significant negative trends $\left(-2 \times 10^{-3}\right.$ to $-5.0 \times 10^{-4} \mathrm{yr}^{-1}$ ) over Mongolia/Inner Mongolia which is not captured by the simulation. There is also a small area of statistically significant positive UVAI trends $\left(1.5 \times 10^{-3}\right.$ to $2.0 \times 10^{-3} \mathrm{yr}^{-1}$ ) in OMI values of over Central Asia between the Caspian Sea and the Aral Sea which is not captured by the simulation. Trends in surface reflectance from the diminishing Aral Sea cannot solely explain the UVAI trends since they extend over the Caspian Sea. Trends in mineral dust are a more likely explanation as discussed further below.

Figures 5 and 6 show the seasonality of the OMI and simulated UVAI trends respectively. The positive UVAI trends over the eastern United States are strongest in summer (JJA) for both OMI and the simulation. The positive UVAI trends over North Africa and the Middle East are present for all seasons for OMI and for most seasons in the simulation, except in JJA for North Africa and spring (MAM) for the Middle East. The simulation underestimates the observed UVAI trend over North Africa in SON, perhaps related to an underestimation in trends in mineral dust emissions in the simulation during this season. He et al. (2014) examined the 20002010 trends in global surface albedo using the Global Land Surface Satellites (GLASS) dataset and found no significant trends over this region during SON. The negative trend in UVAI values over West Africa is most apparent in the fall (SON) and winter (DJF) for both OMI and the simulation. The negative OMI UVAI trends over Mongolia/Inner Mongolia and the positive OMI UVAI trends near the Aral Sea are strongest in JJA and weakest in DJF, providing evidence of a mineral dust source. The OMI UVAI trend over Mongolia/Inner Mongolia may be part of a longer-term trend. Guan et al. (2017) examined dust storm data over northern China (including Inner Mongolia) for the period 1960-2007 and found that dust storm frequency has been declining over the region due to a gradual decrease in wind speed. The current generation of chemical transport models is unlikely to represent the source near the Aral Sea without an explicit parameterization of the drying sea. The desiccation of the Aral Sea over recent decades has resulted in a steady decline in water coverage over the area (Shi et al., 2014; Shi and Wang, 2015) and has led to the dried up sea bed becoming an increasing source of dust activity in the region (Spivak et al., 2012). Indoitu et al. (2015) found that most dust events are directed towards the west, consistent with the OMI observations. An increase in surface reflectance due to the drying up of the sea bed could also positively influence trends in UVAI. He et al. (2014) found a positive trend over 2000-2010 in sur- 

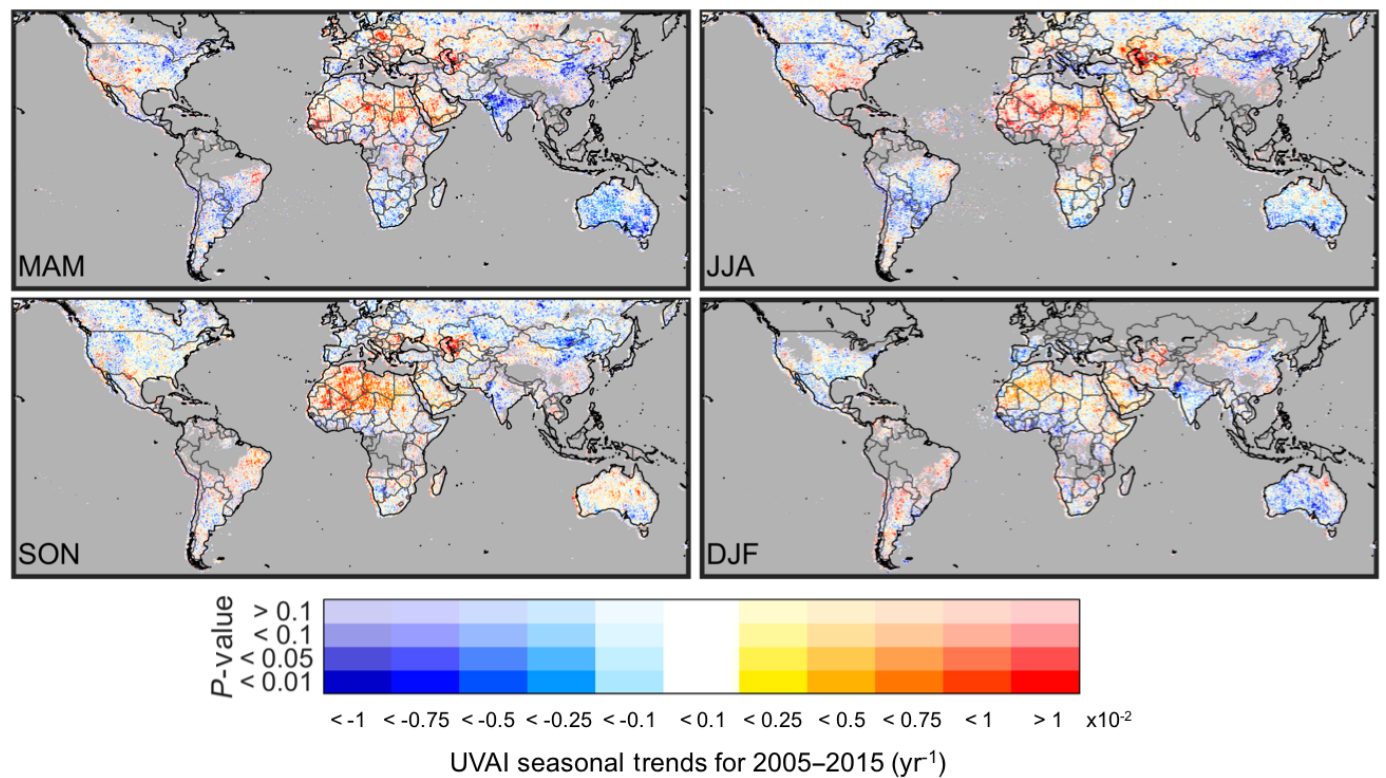

Figure 5. Seasonality of the trends in OMI UVAI values calculated from the generalized least squares regression of monthly time series values during 2005-2015 for MAM (May, April, March), JJA (June, July August), SON (September, October, November), and DJF (December, January, February). The opacity of the colours indicates the statistical significance of the trend. Grey indicates persistent cloud fraction greater than $5 \%$.

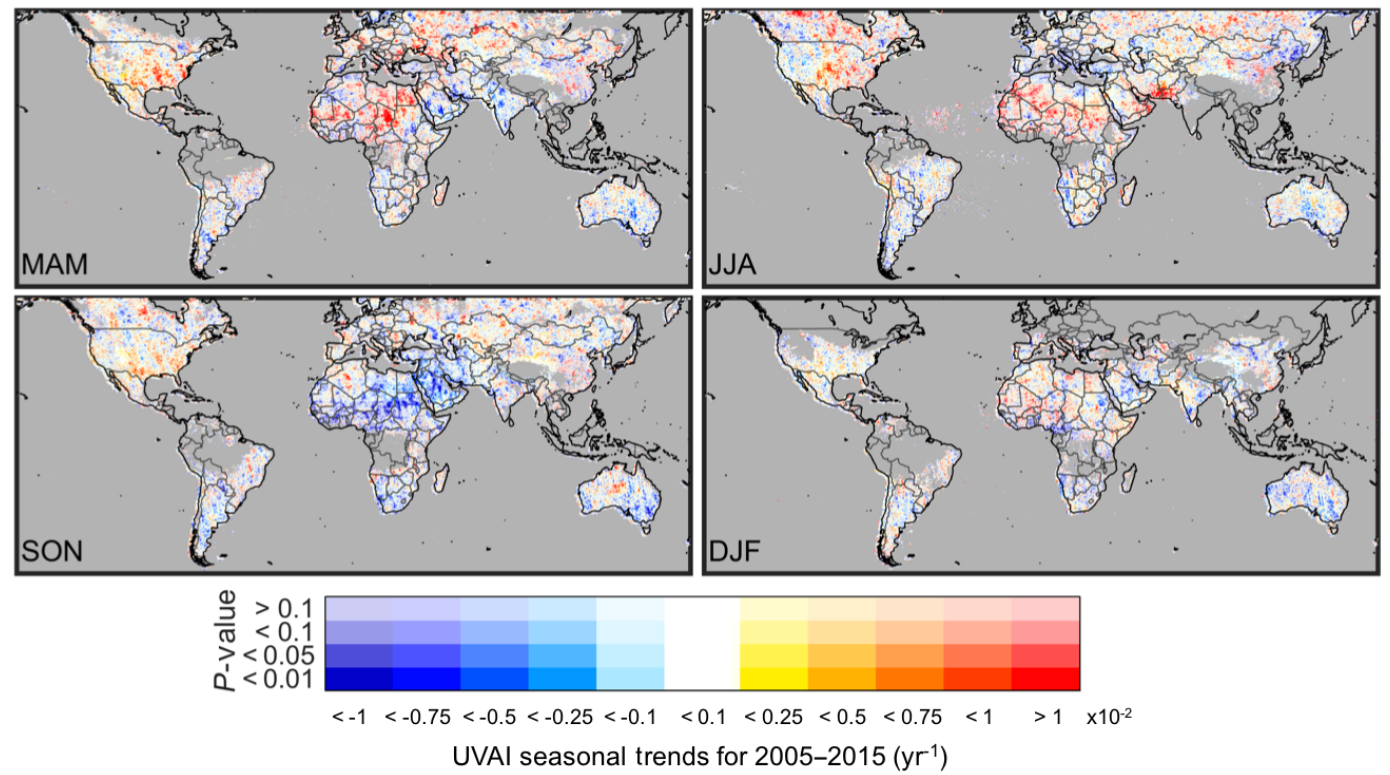

Figure 6. Seasonality of the trends in simulated UVAI values coincidently sampled from OMI calculated from the generalized least squares regression of monthly time series values during 2005-2015 for MAM (May, April, March), JJA (June, July August), SON (September, October, November), and DJF (December, January, February). The opacity of the colours indicates the statistical significance of the trend. Grey indicates persistent cloud fraction greater than $5 \%$.

face albedo over the region in JJA and SON, corresponding to when the OMI UVAI trends are strongest.

\section{Contribution of individual aerosol species to the simulated UVAI}

To further interpret the UVAI trends, we examine the trends in aerosol concentrations from our GEOS-Chem 

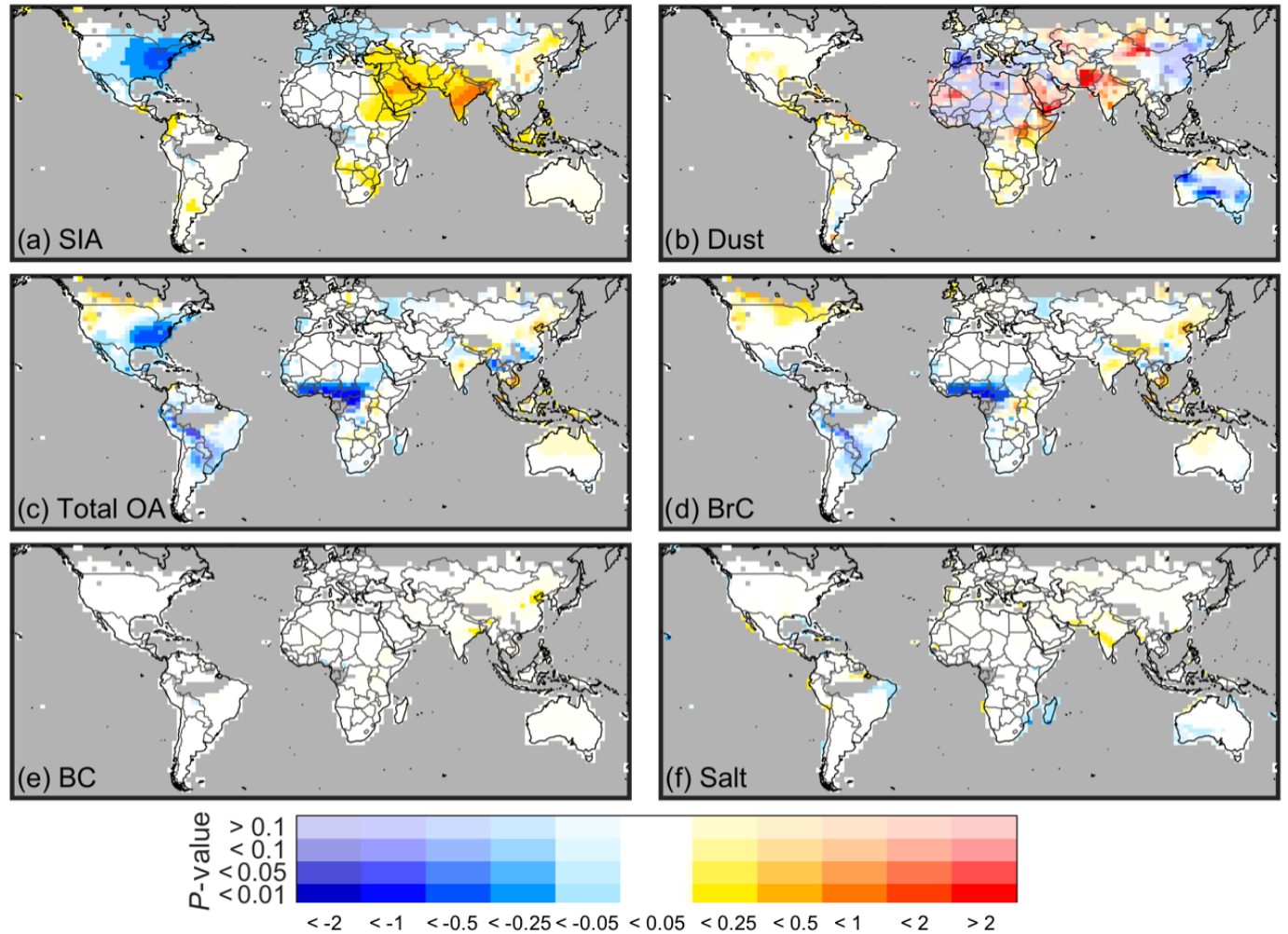

GEOS-Chem aerosol concentration trends for 2005-2015 $\left(\mu \mathrm{g} \mathrm{m}^{-2} \mathrm{yr}^{-1}\right)$

Figure 7. Trend in GEOS-Chem aerosol concentrations for (a) secondary inorganic aerosol (SIA), (b) dust, (c) total organic aerosol (OA), (d) brown carbon $(\mathrm{BrC})$, (e) black carbon (BC), and (f) sea salt. The trends are calculated from the GLS regression of monthly aerosol concentration time series values during 2005-2015. The opacity of the colours indicates the statistical significance of the trend. Grey indicates persistent cloud fraction greater than $5 \%$.

simulation (Fig. 7). Figure 7a shows the trends in secondary inorganic aerosol (SIA). There are statistically significant negative trends over the eastern United States $(-1$ to $-0.05 \mu \mathrm{g} \mathrm{m}^{-2} \mathrm{yr}^{-1}$ ) and statistically significant positive trends over the Middle East (0.05 to $\left.0.5 \mu \mathrm{g} \mathrm{m}^{-2} \mathrm{yr}^{-1}\right)$, India $\left(0.05\right.$ to $\left.1 \mu \mathrm{g} \mathrm{m}^{-2} \mathrm{yr}^{-1}\right)$, South America, and southern Africa $\left(0.05\right.$ to $\left.0.25 \mu \mathrm{g} \mathrm{m}^{-2} \mathrm{yr}^{-1}\right)$. Figure $7 \mathrm{~b}$ shows the trends in dust. Similar to the trends in emissions, the trends in dust concentrations are of the largest magnitude of the various species, but often with low statistical significance. There are positive trends over the Middle East ( $>2 \mu \mathrm{g} \mathrm{m}^{-2} \mathrm{yr}^{-1}$ ), India (0.05 to $2 \mu \mathrm{g} \mathrm{m}^{-2} \mathrm{yr}^{-1}$ ), and northwest China ( 1 to $2 \mu \mathrm{g} \mathrm{m}^{-2} \mathrm{yr}^{-1}$ ). There are also positive trends ( 0.05 to $0.25 \mu \mathrm{g} \mathrm{m}^{-2} \mathrm{yr}^{-1}$ ) with low statistical significance over the United States, northern South America, southern Africa, and northern Australia. There is a combination of positive and negative trends ( $>2$ and $<-2 \mu \mathrm{g} \mathrm{m}^{-2} \mathrm{yr}^{-1}$ ) over North Africa, and negative trends over China and Mongolia $\left(<-2 \mu \mathrm{g} \mathrm{m}^{-2} \mathrm{yr}^{-1}\right)$ and Australia ( -1 to $-0.5 \mu \mathrm{g} \mathrm{m}^{-2} \mathrm{yr}^{-1}$ ). Figure $7 \mathrm{c}$ and $\mathrm{d}$ show the trends in total organic aerosol (OA) and the absorbing $\mathrm{BrC}$ component of $\mathrm{OA}$, respectively. Positive trends over Canada and parts of Russia (0.05 to
$0.5 \mu \mathrm{g} \mathrm{m}^{-2} \mathrm{yr}^{-1}$ ) in total OA are mainly due to the positive trend in $\mathrm{BrC}$. Statistically significant negative trends in total OA $\left(-1\right.$ to $\left.-0.05 \mu \mathrm{g} \mathrm{m}^{-2} \mathrm{yr}^{-1}\right)$ over the eastern United States are dominated by scattering organic aerosol. Statistically significant negative trends ( -2 to $-0.05 \mu \mathrm{g} \mathrm{m}^{-2} \mathrm{yr}^{-1}$ ) over West Africa and South America for total OA are dominated by the trend in absorbing $\mathrm{BrC}$. Figure $5 \mathrm{e}$ and $\mathrm{f}$ show the trends in $\mathrm{BC}$ and salt, respectively. There are positive trends ( 0.05 to $\left.0.25 \mu \mathrm{g} \mathrm{m}^{-2} \mathrm{yr}^{-1}\right)$ in $\mathrm{BC}$ with low statistical significance over India and China. Sea salt trends are negligible.

To gain further insight into how changes in aerosols effect the trends in simulated UVAI, we examine the sensitivity of the UVAI to changes in individual aerosol species. Figure 8 shows the change in annual mean UVAI due to doubling the concentration of individual aerosol species. This information facilitates interpretation of the observed UVAI trends by identifying the chemical components that could explain the observed trends. Doubling scattering SIA concentrations (Fig. 8a) decreases the UVAI between -0.25 and -0.1 over most of the globe, with the largest changes over the eastern United States, Europe, parts of the Middle East, India, and southeast China. Doubling dust concentrations 

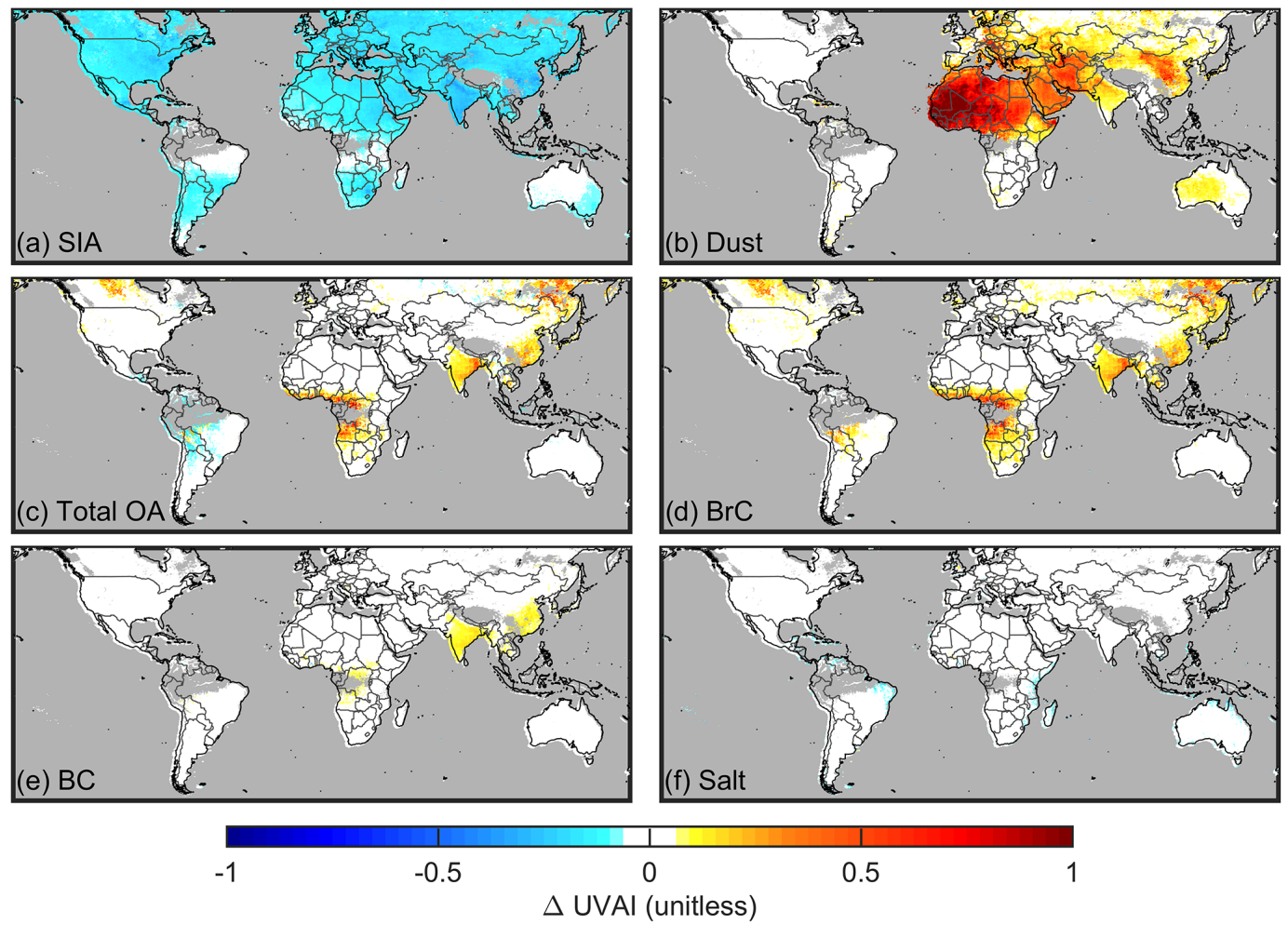

Figure 8. Annual mean change in simulated UVAI values for 2008 due to the doubling of concentrations of (a) secondary inorganic aerosol (SIA), (b) dust, (c) total organic aerosol (OA), (d) brown carbon (BrC), (e) black carbon (BC), and (f) sea salt from the GEOSChem simulation. Grey indicates persistent cloud fraction greater than $5 \%$.

(Fig. 8b) produces the largest changes in UVAI, causing increases between 0.5 and 1 over North Africa and smaller increases between 0.2 and 0.5 over the Middle East, Europe, and parts of Asia and Australia. Figure 8c and d show the changes in UVAI due to doubling total OA concentrations and the absorbing $\mathrm{BrC}$ component, respectively. The doubling of BrC increases the UVAI between 0.1 and 0.5 over Canada, West and Central Africa, India, parts of Russia, eastern China, and central South America. Doubling total OA concentrations over central South America causes a net decrease of $\sim-0.1$ as the scattering component of total OA cancels out the absorption by BrC. Doubling BC concentrations (Fig. 8e) increases the UVAI of 0.1 over Central Africa, India, and southeast China, while doubling sea salt concentrations (Fig. 8f) has negligible effect on the UVAI.

Figure 9 shows the change in simulated UVAI due to the 2005-2015 trends in individual aerosol species from our GEOS-Chem simulation. The change for each species is calculated by applying the aerosol concentration trends for the individual aerosol type while leaving the concentrations unchanged for the other aerosol species, then taking the difference between this perturbed UVAI simulation and an unperturbed simulation. Negative trends in scattering SIA (Fig. 9a) increase the UVAI by $1.0 \times 10^{-4}$ to $7.5 \times 10^{-3} \mathrm{yr}^{-1}$ over the eastern United States and by
$1.0 \times 10^{-4}$ to $2.5 \times 10^{-3} \mathrm{yr}^{-1}$ over Europe, corresponding to regions of positive UVAI trends in both OMI and the simulation (Fig. 4). Increasing SIA decreases the UVAI by $-2.5 \times 10^{-3}$ to $-1.0 \times 10^{-4} \mathrm{yr}^{-1}$ over the Middle East, India, and east China. Trends in dust concentrations (Fig. 9b) cause the largest change in UVAI with regional increases $>1 \times 10^{-2} \mathrm{yr}^{-1}$ and regional decreases $<-1 \times 10^{-2} \mathrm{yr}^{-1}$. Simulated UVAI trends due to mineral dust are mostly negative over North Africa, East Asia, and Australia, while mostly positive over the Middle East. Noisy trends in regional meteorology cause heterogeneous trends in dust and in the UVAI, with low statistical significance. Figure $9 \mathrm{c}$ and $d$ show the change in UVAI due to the trends in total OA and the absorbing $\mathrm{BrC}$ component of total $\mathrm{OA}$, respectively. Most of the changes in UVAI due to the trends in total OA are caused by the trends in the absorbing $\mathrm{BrC}$ component, with increases in the UVAI between $2.5 \times 10^{-3}$ and $1 \times 10^{-2} \mathrm{yr}^{-1}$ over Canada and parts of Russia, corresponding to regions of positive UVAI trends for both OMI and the simulation (Fig. 4). There are decreases in the UVAI $<-1 \times 10^{-2} \mathrm{yr}^{-1}$ over central South America and West Africa due to the negative trends in $\mathrm{BrC}$, corresponding to regions of negative UVAI trends for both OMI and the simulation (Fig. 4). Over the eastern United States there is a mixture of increases and decreases in the UVAI due to the trends in scattering organic 

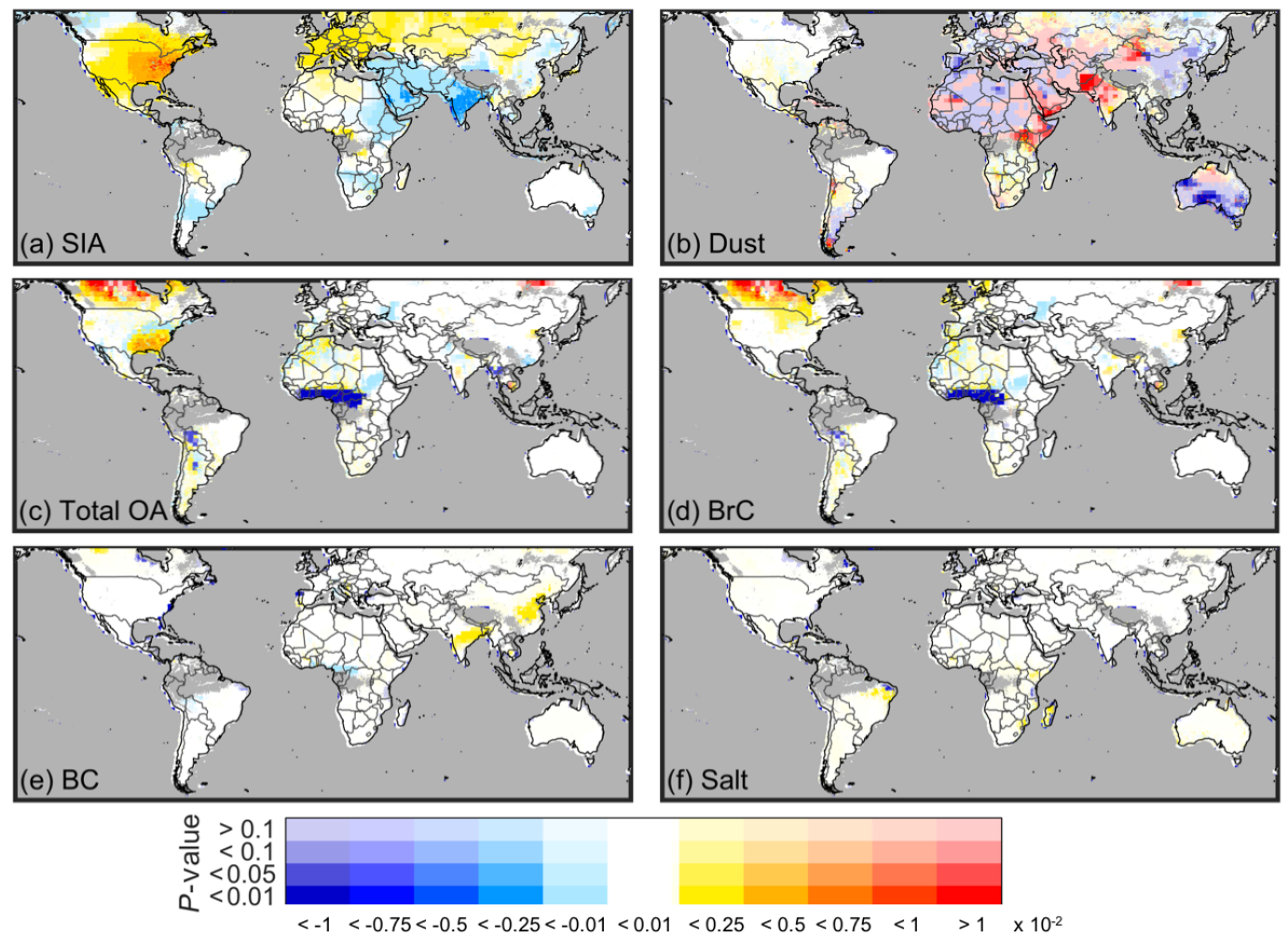

$\triangle$ UVAI $\left(\mathrm{yr}^{-1}\right)$

Figure 9. Change in simulated UVAI values due to the 2005-2015 trends in (a) secondary inorganic aerosols (SIA), (b) dust, (c) total organic aerosol (OA), (d) brown carbon $(\mathrm{BrC})$, (e) black carbon (BC), and (f) sea salt from the GEOS-Chem simulation. Grey indicates persistent cloud fraction greater than $5 \%$.

aerosol. Positive trends in $\mathrm{BC}$ increase the UVAI (Fig. 9e) by $1.0 \times 10^{-4}$ to $2.5 \times 10^{-3} \mathrm{yr}^{-1}$ over India and China. There are no obvious changes in the UVAI due to the trends in sea salt (Fig. 9f).

\section{Conclusions}

Observations of aerosol scattering and absorption offer valuable information about aerosol composition. We simulated the UVAI, a method of detecting aerosol absorption using satellite measurements, to interpret trends in OMI observed UVAI during 2005-2015 to understand global trends in aerosol composition. We conducted our simulation using the vector radiative transfer model VLIDORT with aerosol fields from the global chemical transport model GEOS-Chem.

We demonstrated that interpretation of the OMI UVAI with a quantitative simulation of the UVAI offers information about trends in aerosol composition. We found that global trends in the UVAI were largely explained by trends in absorption by mineral dust, absorption by $\mathrm{BrC}$, and scattering by secondary inorganic aerosols. We also identified areas for model development, such as dust emissions from the desiccating Aral Sea.
We examined the 2005-2015 trends in individual aerosol species from GEOS-Chem and applied these trends to the UVAI simulation to calculate the change in simulated UVAI due to the trends in individual aerosol species. The two most prominent positive trends in the observed UVAI were over North Africa and over Central Asia near the desiccating Aral Sea. The simulated UVAI attributes the positive trends over North Africa to increasing mineral dust despite an underestimated simulated trend in fall (SON) that deserves further attention. The positive trends in the observed UVAI over Central Asia near the shrinking Aral Sea are likely due to increased dust emissions, a feature that is unlikely to be represented in most chemical transport models. The most prominent negative trends in the observed UVAI were over East Asia, South Asia, and Australia. The simulation attributed the negative trends over East Asia and Australia to decreasing mineral dust, despite underestimating the trend in East Asia. The simulation attributed the negative trend over South Asia to increasing scattering secondary inorganic aerosols, a trend that the observations imply could be even larger. We found the positive trends in the UVAI over the eastern United States that were strongest in summer (JJA) in both the observations and the simulation were driven by negative trends in 
scattering secondary inorganic aerosol and organic aerosol. Observed negative trends in winter (DJF) were less well simulated. Over West Africa and South America, negative trends in UVAI were explained by negative trends in absorbing $\mathrm{BrC}$. Thus, trends in the observed UVAI offer valuable information on the evolution of global aerosol composition that can be understood through quantitative simulation of the UVAI.

Looking forward, the availability of the UVAI observations from 1979 to the present offers a unique opportunity to understand long-term trends in aerosol composition. The recent launch of the TROPOspheric Monitoring Instrument (TROPOMI; Veefkind et al., 2012) and the forthcoming geostationary constellation offer UVAI observations at finer spatial and temporal resolution. The forthcoming Multi-Angle Imager for Aerosols (MAIA; Diner et al., 2018) satellite instrument offers an exciting opportunity to derive even more information about aerosol composition by combining measurements at ultraviolet wavelengths with multi-angle observations and polarization sensitivity.

Data availability. The OMAERUV UVAI dataset (version 1.8.9.1) used in this study is available from the NASA Goddard Earth Sciences Data and Information Services Center (https://disc.sci.gsfc. nasa.gov/datasets/OMAERUV_V003/summary; last access: 22 August 2017). The GEOS-Chem chemical transport model used here is available at www.geos-chem.org (last access: 20 August 2017). The VLIDORT radiative transfer model (Spurr, 2006) is available at http://www.rtslidort.com/mainprod_vlidort.html (last access: 7 April 2016).

\section{The Supplement related to this article is available online at https://doi.org/10.5194/acp-18-8097-2018-supplement.}

Competing interests. The authors declare that they have no conflict of interest.

Acknowledgements. This work was supported by the Natural Science and Engineering Research Council of Canada and the Killam Trusts. Computational facilities were provided in part by the Atlantic Computational Excellence Network and the Graham consortiums of Compute Canada.

Edited by: Kostas Tsigaridis

Reviewed by: two anonymous referees

\section{References}

Andela, N. and van der Werf, G. R.: Recent trends in African fires driven by cropland expansion and El Niño to La Niña transition, Nat. Clim. Chang., 4, 791-795, https://doi.org/10.1038/nclimate2313, 2014.
Andreae, M. O. and Gelencsér, A.: Black carbon or brown carbon? The nature of light-absorbing carbonaceous aerosols, Atmos. Chem. Phys., 6, 3131-3148, https://doi.org/10.5194/acp-63131-2006, 2006.

Badarinath, K. V. S., Kharol, S. K., Kaskaoutis, D. G., Sharma, A. R., Ramaswamy, V., and Kambezidis, H. D.: Long-range transport of dust aerosols over the Arabian Sea and Indian region - A case study using satellite data and groundbased measurements, Global Planet. Change, 72, 164-181, https://doi.org/10.1016/j.gloplacha.2010.02.003, 2010.

Bey, I., Jacob, D. J., Yantosca, R. M., Logan, J. A., Field, B. D., Fiore, A. M., Li, Q., Liu, H. Y., Mickley, L. J., and Schultz, M. G.: Global modeling of tropospheric chemistry with assimilated meteorology: Model description and evaluation, J. Geophys. Res., 106, 23073, https://doi.org/10.1029/2001JD000807, 2001.

Bond, T. C., Doherty, S. J., Fahey, D. W., Forster, P. M., Berntsen, T., DeAngelo, B. J., Flanner, M. G., Ghan, S., Kärcher, B., Koch, D., Kinne, S., Kondo, Y., Quinn, P. K., Sarofim, M. C., Schultz, M. G., Schulz, M., Venkataraman, C., Zhang, H., Zhang, S., Bellouin, N., Guttikunda, S. K., Hopke, P. K., Jacobson, M. Z., Kaiser, J. W., Klimont, Z., Lohmann, U., Schwarz, J. P., Shindell, D., Storelvmo, T., Warren, S. G., and Zender, C. S.: Bounding the role of black carbon in the climate system: A scientific assessment, J. Geophys. Res.-Atmos., 118, 5380-5552, https://doi.org/10.1002/jgrd.50171, 2013.

Boys, B. L., Martin, R. V., van Donkelaar, A., MacDonell, R. J., Hsu, N. C., Cooper, M. J., Yantosca, R. M., Lu, Z., Streets, D. G., Zhang, Q., and Wang, S. W.: Fifteen-Year Global Time Series of Satellite-Derived Fine Particulate Matter, Environ. Sci. Technol., 48, 11109-11118, https://doi.org/10.1021/es502113p, 2014.

Buchard, V., da Silva, A. M., Colarco, P. R., Darmenov, A., Randles, C. A., Govindaraju, R., Torres, O., Campbell, J., and Spurr, R.: Using the OMI aerosol index and absorption aerosol optical depth to evaluate the NASA MERRA Aerosol Reanalysis, Atmos. Chem. Phys., 15, 5743-5760, https://doi.org/10.5194/acp15-5743-2015, 2015.

Chen, Y., Morton, D. C., Jin, Y., Collatz, G. J., Kasibhatla, P. S., van der Werf, G. R., DeFries, R. S., and Randerson, J. T.: Longterm trends and interannual variability of forest, savanna and agricultural fires in South America, Carbon Manag., 4, 617-638, https://doi.org/10.4155/cmt.13.61, 2013.

Chin, M., Diehl, T., Tan, Q., Prospero, J. M., Kahn, R. A., Remer, L. A., Yu, H., Sayer, A. M., Bian, H., Geogdzhayev, I. V., Holben, B. N., Howell, S. G., Huebert, B. J., Hsu, N. C., Kim, D., Kucsera, T. L., Levy, R. C., Mishchenko, M. I., Pan, X., Quinn, P. K., Schuster, G. L., Streets, D. G., Strode, S. A., Torres, O., and Zhao, X.-P.: Multi-decadal aerosol variations from 1980 to 2009: a perspective from observations and a global model, Atmos. Chem. Phys., 14, 3657-3690, https://doi.org/10.5194/acp14-3657-2014, 2014.

Crippa, M., Janssens-Maenhout, G., Dentener, F., Guizzardi, D., Sindelarova, K., Muntean, M., Van Dingenen, R., and Granier, C.: Forty years of improvements in European air quality: regional policy-industry interactions with global impacts, Atmos. Chem. Phys., 16, 3825-3841, https://doi.org/10.5194/acp-163825-2016, 2016.

Cui, H., Mao, P., Zhao, Y., Nielsen, C. P., and Zhang, J.: Patterns in atmospheric carbonaceous aerosols in China: emission estimates 
and observed concentrations, Atmos. Chem. Phys., 15, 86578678, https://doi.org/10.5194/acp-15-8657-2015, 2015.

Curci, G., Hogrefe, C., Bianconi, R., Im, U., Balzarini, A., Baró, R., Brunner, D., Forkel, R., Giordano, L., Hirtl, M., Honzak, L., Jiménez-Guerrero, P., Knote, C., Langer, M., Makar, P. A., Pirovano, G., Pérez, J. L., San José, R., Syrakov, D., Tuccella, P., Werhahn, J., Wolke, R., Žabkar, R., Zhang, J., and Galmarini, S.: Uncertainties of simulated aerosol optical properties induced by assumptions on aerosol physical and chemical properties: An AQMEII-2 perspective, Atmos. Environ., 115, 541552, https://doi.org/10.1016/j.atmosenv.2014.09.009, 2015.

Curier, L., Kranenburg, R., Timmermans, R., Segers, A., Eskes, H., and Schaap, M.: Synergistic Use of LOTOS-EUROS and $\mathrm{NO}_{2}$ Tropospheric Columns to Evaluate the $\mathrm{NO}_{x}$ Emission Trends Over Europe, 239-245, 2014.

Dai, A.: Recent Climatology, Variability, and Trends in Global Surface Humidity, J. Climate, 19, 3589-3606, https://doi.org/10.1175/JCLI3816.1, 2006.

de Graaf, M., Stammes, P., Torres, O., and Koelemeijer, R. B. A.: Absorbing Aerosol Index: Sensitivity analysis, application to GOME and comparison with TOMS, J. Geophys. Res., 110, D01201, https://doi.org/10.1029/2004JD005178, 2005.

Deirmendjian, D.: Scattering and Polarization Properties of Water Clouds and Hazes in the Visible and Infrared, Appl. Opt., 3, 187196, https://doi.org/10.1364/AO.3.000187, 1964.

de Meij, A., Pozzer, A., and Lelieveld, J.: Trend analysis in aerosol optical depths and pollutant emission estimates between 2000 and 2009, Atmos. Environ., 51, 75-85, https://doi.org/10.1016/j.atmosenv.2012.01.059, 2012.

Dey, S. and Di Girolamo, L.: A decade of change in aerosol properties over the Indian subcontinent, Geophys. Res. Lett., 38, L14811, https://doi.org/10.1029/2011GL048153, 2011.

Diner, D. J., Brauer, M., Bruegge, C., Burke, K. A., Chipman, R., Di Girolamo, L., Garay, M. J., Hasheminassab, S., Hyer, E., Jerrett, M., Jovanovic, V., Kalashnikova, O. V., Liu, Y., Lyapustin, A. I., Martin., R. V., Nastan, A., Ostro, B. D., Ritz, B., Schwartz, J., Wang, J., and Xua, F.: Advances in multiangle satellite remote sensing of speciated airborne particulate matter and association with adverse health effects: from MISR to MAIA, J. Appl. Remote Sens., submitted, 2018.

Drury, E., Jacob, D. J., Spurr, R. J. D., Wang, J., Shinozuka, Y., Anderson, B. E., Clarke, A. D., Dibb, J., McNaughton, C., and Weber, R.: Synthesis of satellite (MODIS), aircraft (ICARTT), and surface (IMPROVE, EPA-AQS, AERONET) aerosol observations over eastern North America to improve MODIS aerosol retrievals and constrain surface aerosol concentrations and sources, J. Geophys. Res., 115, D14204, https://doi.org/10.1029/2009JD012629, 2010.

Duncan, B. N., Martin, R. V., Staudt, A. C., Yevich, R., and Logan, J. A.: Interannual and seasonal variability of biomass burning emissions constrained by satellite observations, J. Geophys. Res., 108, 4100, https://doi.org/10.1029/2002JD002378, 2003.

Fairlie, D. J., Jacob, D. J., and Park, R. J.: The impact of transpacific transport of mineral dust in the United States, Atmos. Environ., 41, 1251-1266, https://doi.org/10.1016/j.atmosenv.2006.09.048, 2007.

Fioletov, V. E., McLinden, C. A., Krotkov, N., Li, C., Joiner, J., Theys, N., Carn, S., and Moran, M. D.: A global catalogue of large $\mathrm{SO}_{2}$ sources and emissions derived from the Ozone
Monitoring Instrument, Atmos. Chem. Phys., 16, 11497-11519, https://doi.org/10.5194/acp-16-11497-2016, 2016.

Fountoukis, C. and Nenes, A.: ISORROPIA II: a computationally efficient thermodynamic equilibrium model for $\mathrm{K}^{+}$ $\mathrm{Ca}_{+}^{2}-\mathrm{Mg}_{+}^{2}-\mathrm{NH}_{4}^{+}-\mathrm{Na}^{+}-\mathrm{SO}_{4}^{2-}-\mathrm{NO}_{3}-\mathrm{Cl}-\mathrm{H}_{2} \mathrm{O}$ aerosols, Atmos. Chem. Phys., 7, 4639-4659, https://doi.org/10.5194/acp-7-46392007, 2007.

Giglio, L., Randerson, J. T., and van der Werf, G. R.: Analysis of daily, monthly, and annual burned area using the fourthgeneration global fire emissions database (GFED4), J. Geophys. Res.-Biogeo., 118, 317-328, https://doi.org/10.1002/jgrg.20042, 2013.

Ginoux, P., Prospero, J. M., Gill, T. E., Hsu, N. C., and Zhao, M.: Global-scale attribution of anthropogenic and natural dust sources and their emission rates based on MODIS Deep Blue aerosol products, Rev. Geophys., 50, RG3005, https://doi.org/10.1029/2012RG000388, 2012.

Guan, H., Esswein, R., Lopez, J., Bergstrom, R., Warnock, A., Follette-Cook, M., Fromm, M., and Iraci, L. T.: A multi-decadal history of biomass burning plume heights identified using aerosol index measurements, Atmos. Chem. Phys., 10, 6461-6469, https://doi.org/10.5194/acp-10-6461-2010, 2010.

Guan, Q., Sun, X., Yang, J., Pan, B., Zhao, S., Wang, L., Guan, Q., Sun, X., Yang, J., Pan, B., Zhao, S., and Wang, L.: Dust Storms in Northern China: Long-Term Spatiotemporal Characteristics and Climate Controls, J. Climate, 30, 6683-6700, https://doi.org/10.1175/JCLI-D-16-0795.1, 2017.

Guan, X., Huang, J., Zhang, Y., Xie, Y., and Liu, J.: The relationship between anthropogenic dust and population over global semi-arid regions, Atmos. Chem. Phys., 16, 5159-5169, https://doi.org/10.5194/acp-16-5159-2016, 2016.

Guo, Y., Tian, B., Kahn, R. A., Kalashnikova, O., Wong, S., and Waliser, D. E.: Tropical Atlantic dust and smoke aerosol variations related to the Madden-Julian Oscillation in MODIS and MISR observations, J. Geophys. Res.-Atmos., 118, 4947-4963, https://doi.org/10.1002/jgrd.50409, 2013.

Hammer, M. S., Martin, R. V., van Donkelaar, A., Buchard, V., Torres, O., Ridley, D. A., and Spurr, R. J. D.: Interpreting the ultraviolet aerosol index observed with the OMI satellite instrument to understand absorption by organic aerosols: implications for atmospheric oxidation and direct radiative effects, Atmos. Chem. Phys., 16, 2507-2523, https://doi.org/10.5194/acp16-2507-2016, 2016.

He, T., Liang, S., and Song, D.-X.: Analysis of global land surface albedo climatology and spatial-temporal variation during 19812010 from multiple satellite products, J. Geophys. Res. Atmos., 119, 10281-10298, https://doi.org/10.1002/2014JD021667, 2014.

Heald, C. L., Collett Jr., J. L., Lee, T., Benedict, K. B., Schwandner, F. M., Li, Y., Clarisse, L., Hurtmans, D. R., Van Damme, M., Clerbaux, C., Coheur, P.-F., Philip, S., Martin, R. V., and Pye, H. O. T.: Atmospheric ammonia and particulate inorganic nitrogen over the United States, Atmos. Chem. Phys., 12, 10295-10312, https://doi.org/10.5194/acp-12-10295-2012, 2012.

Herman, J. R., Bhartia, P. K., Torres, O., Hsu, C., Seftor, C., and Celarier, E.: Global distribution of UV-absorbing aerosols from Nimbus 7/TOMS data, J. Geophys. Res., 102, 16911, https://doi.org/10.1029/96JD03680, 1997. 
Hsu, N. C., Gautam, R., Sayer, A. M., Bettenhausen, C., Li, C., Jeong, M. J., Tsay, S.-C., and Holben, B. N.: Global and regional trends of aerosol optical depth over land and ocean using SeaWiFS measurements from 1997 to 2010, Atmos. Chem. Phys., 12, 8037-8053, https://doi.org/10.5194/acp-12-8037-2012, 2012.

Huang, J., Minnis, P., Yan, H., Yi, Y., Chen, B., Zhang, L., and Ayers, J. K.: Dust aerosol effect on semi-arid climate over Northwest China detected from A-Train satellite measurements, Atmos. Chem. Phys., 10, 6863-6872, https://doi.org/10.5194/acp10-6863-2010, 2010.

Huang, J. P., Liu, J. J., Chen, B., and Nasiri, S. L.: Detection of anthropogenic dust using CALIPSO lidar measurements, Atmos. Chem. Phys., 15, 11653-11665, https://doi.org/10.5194/acp-1511653-2015, 2015.

Indoitu, R., Kozhoridze, G., Batyrbaeva, M., Vitkovskaya, I., Orlovsky, N., Blumberg, D., and Orlovsky, L.: Dust emission and environmental changes in the dried bottom of the Aral Sea, Aeolian Res., 17, 101-115, https://doi.org/10.1016/j.aeolia.2015.02.004, 2015.

IPCC: Climate Change 2014: Impacts, Adaptation, and Vulnerability. Part A: Global and Sectoral Aspects, Contribution of Working Group II to the Fifth Assessment Report of the Intergovernmental Panel on Climate Change, edited by: Field, C. B., Barros, V. R., and Dokken, D. J., Cambridge University Press, Cambridge, United Kingdom and New York, NY, USA, 2014.

Israelevich, P. L., Levin, Z., Joseph, J. H., and Ganor, E.: Desert aerosol transport in the Mediterranean region as inferred from the TOMS aerosol index, J. Geophys. Res.-Atmos., 107, AAC 13-1AAC 13-13, https://doi.org/10.1029/2001JD002011, 2002.

Jaeglé, L., Quinn, P. K., Bates, T. S., Alexander, B., and Lin, J.-T.: Global distribution of sea salt aerosols: new constraints from in situ and remote sensing observations, Atmos. Chem. Phys., 11, 3137-3157, https://doi.org/10.5194/acp-11-3137-2011, 2011.

Jethva, H. and Torres, O.: Satellite-based evidence of wavelengthdependent aerosol absorption in biomass burning smoke inferred from Ozone Monitoring Instrument, Atmos. Chem. Phys., 11, 10541-10551, https://doi.org/10.5194/acp-11-10541-2011, 2011.

Kahn, R. A. and Gaitley, B. J.: An analysis of global aerosol type as retrieved by MISR, J. Geophys. Res.-Atmos., 120, 4248-4281, https://doi.org/10.1002/2015JD023322, 2015.

Kalashnikova, O. V. and Kahn, R. A.: Mineral dust plume evolution over the Atlantic from MISR and MODIS aerosol retrievals, J. Geophys. Res., 113, D24204, https://doi.org/10.1029/2008JD010083, 2008.

Kaskaoutis, D. G., Kharol, S. K., Sifakis, N., Nastos, P. T., Sharma, A. R., Badarinath, K. V. S., and Kambezidis, H. D.: Satellite monitoring of the biomass-burning aerosols during the wildfires of August 2007 in Greece: Climate implications, Atmos. Environ., 45, 716-726, https://doi.org/10.1016/j.atmosenv.2010.09.043, 2011.

Klimont, Z., Smith, S. J., and Cofala, J.: The last decade of global anthropogenic sulfur dioxide: 2000-2011 emissions, Environ. Res. Lett., 8, 14003, https://doi.org/10.1088/17489326/8/1/014003, 2013.

Klimont, Z., Kupiainen, K., Heyes, C., Purohit, P., Cofala, J., Rafaj, P., Borken-Kleefeld, J., and Schöpp, W.: Global anthropogenic emissions of particulate matter including black carbon, Atmos.
Chem. Phys., 17, 8681-8723, https://doi.org/10.5194/acp-178681-2017, 2017.

Koepke, P., Hess, M., Schult, I., and Shettle, E. P.: Global Aerosol Dataset, report, Max-Planck Inst. fur Meteorol., Hamburg, Germany, 1997.

Kristiansen, N. I., Stohl, A., Olivié, D. J. L., Croft, B., Søvde, O. A., Klein, H., Christoudias, T., Kunkel, D., Leadbetter, S J., Lee, Y. H., Zhang, K., Tsigaridis, K., Bergman, T., Evangeliou, N., Wang, H., Ma, P.-L., Easter, R. C., Rasch, P. J., Liu, X., Pitari, G., Di Genova, G., Zhao, S. Y., Balkanski, Y., Bauer, S. E., Faluvegi, G. S., Kokkola, H., Martin, R. V., Pierce, J. R., Schulz, M., Shindell, D., Tost, H., and Zhang, H.: Evaluation of observed and modelled aerosol lifetimes using radioactive tracers of opportunity and an ensemble of 19 global models, Atmos. Chem. Phys., 16, 3525-3561, https://doi.org/10.5194/acp16-3525-2016, 2016.

Kuhns, H., Knipping, E. M., and Vukovich, J. M.: Development of a United States-Mexico Emissions Inventory for the Big Bend Regional Aerosol and Visibility Observational (BRAVO) Study, J. Air Waste Manage., 55, 677-692, https://doi.org/10.1080/10473289.2005.10464648, 2005.

Lee, C., Martin, R. V., van Donkelaar, A., O’Byrne, G., Krotkov, N., Richter, A., Huey, L. G., and Holloway, J. S.: Retrieval of vertical columns of sulfur dioxide from SCIAMACHY and OMI: Air mass factor algorithm development, validation, and error analysis, J. Geophys. Res., 114, D22303, https://doi.org/10.1029/2009JD012123, 2009.

Leibensperger, E. M., Mickley, L. J., Jacob, D. J., Chen, W.-T., Seinfeld, J. H., Nenes, A., Adams, P. J., Streets, D. G., Kumar, N., and Rind, D.: Climatic effects of 1950-2050 changes in US anthropogenic aerosols - Part 2: Climate response, Atmos. Chem. Phys., 12, 3349-3362, https://doi.org/10.5194/acp12-3349-2012, 2012.

Li, C., Martin, R. V., van Donkelaar, A., Boys, B. L., Hammer, M. S., Xu, J.-W., Marais, E. A., Reff, A., Strum, M., Ridley, D. A., Crippa, M., Brauer, M., and Zhang, Q.: Trends in Chemical Composition of Global and Regional Population-Weighted Fine Particulate Matter Estimated for 25 Years, Environ. Sci. Technol., 51, 11185-11195, https://doi.org/10.1021/acs.est.7b02530, 2017.

Li, J., Carlson, B. E., Dubovik, O., and Lacis, A. A.: Recent trends in aerosol optical properties derived from AERONET measurements, Atmos. Chem. Phys., 14, 1227112289, https://doi.org/10.5194/acp-14-12271-2014, 2014.

Li, M., Zhang, Q., Kurokawa, J.-I., Woo, J.-H., He, K., Lu, Z., Ohara, T., Song, Y., Streets, D. G., Carmichael, G. R., Cheng, Y., Hong, C., Huo, H., Jiang, X., Kang, S., Liu, F., Su, H., and Zheng, B.: MIX: a mosaic Asian anthropogenic emission inventory under the international collaboration framework of the MICS-Asia and HTAP, Atmos. Chem. Phys., 17, 935-963, https://doi.org/10.5194/acp-17-935-2017, 2017.

Liu, F., Zhang, Q., van der A, R. J., Zheng, B., Tong, D., Yan, L., Zheng, Y., and He, K.: Recent reduction in $\mathrm{NO}_{x}$ emissions over China: synthesis of satellite observations and emission inventories, Environ. Res. Lett., 11, 114002, https://doi.org/10.1088/1748-9326/11/11/114002, 2016.

Liu, Y., Koutrakis, P., and Kahn, R.: Estimating fine particulate matter component concentrations and size distributions using satellite-retrieved fractional aerosol optical depth: part 1 - 
method development., J. Air Waste Manage., 57, 1351-1359, https://doi.org/10.3155/1047-3289.57.11.1351, 2007.

Lu, Z., Zhang, Q., and Streets, D. G.: Sulfur dioxide and primary carbonaceous aerosol emissions in China and India, 1996-2010, Atmos. Chem. Phys., 11, 9839-9864, https://doi.org/10.5194/acp-11-9839-2011, 2011.

Ma, Z., Hu, X., Sayer, A. M., Levy, R., Zhang, Q., Xue, Y., Tong, S., Bi, J., Huang, L., and Liu, Y.: SatelliteBased Spatiotemporal Trends in $\mathrm{PM}_{2.5}$ Concentrations: China, 2004-2013, Environ. Health Persp., 124, 184-92, https://doi.org/10.1289/ehp.1409481, 2016.

Mann, M. E. and Emanuel, K. A.: Atlantic hurricane trends linked to climate change, EOS T. Am. Geophys. Un., 87, 233-241, https://doi.org/10.1029/2006EO240001, 2006.

Mao, K. B., Ma, Y., Xia, L., Chen, W. Y., Shen, X. Y., He, T. J., and $\mathrm{Xu}, \mathrm{T}$. R.: Global aerosol change in the last decade: An analysis based on MODIS data, Atmos. Environ., 94, 680-686, https://doi.org/10.1016/j.atmosenv.2014.04.053, 2014.

Marais, E. A., Jacob, D. J., Jimenez, J. L., Campuzano-Jost, P., Day, D. A., Hu, W., Krechmer, J., Zhu, L., Kim, P. S., Miller, C. C., Fisher, J. A., Travis, K., Yu, K., Hanisco, T. F., Wolfe, G. M., Arkinson, H. L., Pye, H. O. T., Froyd, K. D., Liao, J., and McNeill, V. F.: Aqueous-phase mechanism for secondary organic aerosol formation from isoprene: application to the southeast United States and co-benefit of $\mathrm{SO}_{2}$ emission controls, Atmos. Chem. Phys., 16, 1603-1618, https://doi.org/10.5194/acp16-1603-2016, 2016.

Martin, R. V., Jacob, D. J., Yantosca, R. M., Chin, M., and Ginoux, P.: Global and regional decreases in tropospheric oxidants from photochemical effects of aerosols, J. Geophys. Res., 108, 4097, https://doi.org/10.1029/2002JD002622, 2003.

Mauritsen, T.: Arctic climate change: Greenhouse warming unleashed, Nat. Geosci., 9, 271-272, https://doi.org/10.1038/ngeo2677, 2016.

Mehta, M., Singh, R., Singh, A., Singh, N., and Anshumali: Recent global aerosol optical depth variations and trends - A comparative study using MODIS and MISR level 3 datasets, Remote Sens. Environ., 181, 137-150, https://doi.org/10.1016/j.rse.2016.04.004, 2016.

Mielonen, T., Portin, H., Komppula, M., Leskinen, A., Tamminen, J., Ialongo, I., Hakkarainen, J., Lehtinen, K. E. J., and Arola, A.: Biomass burning aerosols observed in Eastern Finland during the Russian wildfires in summer 2010 - Part 2: Remote sensing, Atmos. Environ., 47, 279-287, https://doi.org/10.1016/j.atmosenv.2011.07.016, 2012.

Moosmüller, H., Chakrabarty, R. K., and Arnott, W. P.: Aerosol light absorption and its measurement: A review, J. Quant. Spectrosc. Ra., 110, 844-878, https://doi.org/10.1016/j.jqsrt.2009.02.035, 2009.

Norris, J. R. and Wild, M.: Trends in aerosol radiative effects over Europe inferred from observed cloud cover, solar "dimming," and solar "brightening," J. Geophys. Res., 112, D08214, https://doi.org/10.1029/2006JD007794, 2007.

Park, R. J., Jacob, D. J., Chin, M., and Martin, R. V.: Sources of carbonaceous aerosols over the United States and implications for natural visibility, J. Geophys. Res., 108, 4355, https://doi.org/10.1029/2002JD003190, 2003.

Park, R. J., Jacob, D. J., Field, B. D., Yantosca, R. M., and Chin, M.: Natural and transboundary pollution influ- ences on sulfate-nitrate-ammonium aerosols in the United States: Implications for policy, J. Geophys. Res., 109, D15204, https://doi.org/10.1029/2003JD004473, 2004.

Pelletier, J. D. and Turcotte, D. L.: Long-range persistence in climatological and hydrological time series: analysis, modeling and application to drought hazard assessment, J. Hydrol., 203, 198208, https://doi.org/10.1016/S0022-1694(97)00102-9, 1997.

Penning de Vries, M. J. M., Beirle, S., and Wagner, T.: UV Aerosol Indices from SCIAMACHY: introducing the SCattering Index (SCI), Atmos. Chem. Phys., 9, 9555-9567, https://doi.org/10.5194/acp-9-9555-2009, 2009.

Penning de Vries, M. J. M., Beirle, S., Hörmann, C., Kaiser, J. W., Stammes, P., Tilstra, L. G., Tuinder, O. N. E., and Wagner, T.: A global aerosol classification algorithm incorporating multiple satellite data sets of aerosol and trace gas abundances, Atmos. Chem. Phys., 15, 10597-10618, https://doi.org/10.5194/acp-1510597-2015, 2015.

Philip, S., Martin, R. V, Snider, G., Weagle, C. L., van Donkelaar, A., Brauer, M., Henze, D. K., Klimont, Z., Venkataraman, C., Guttikunda, S. K., and Zhang, Q.: Anthropogenic fugitive, combustion and industrial dust is a significant, underrepresented fine particulate matter source in global atmospheric models, Environ. Res. Lett., 12, 44018, https://doi.org/10.1088/1748-9326/aa65a4, 2017.

Pöschl, U.: Atmospheric Aerosols: Composition, Transformation, Climate and Health Effects, Angew. Chem. Int. Edit., 44, 7520 7540, https://doi.org/10.1002/anie.200501122, 2005.

Povey, A. C. and Grainger, R. G.: Known and unknown unknowns: uncertainty estimation in satellite remote sensing, Atmos. Meas. Tech., 8, 4699-4718, https://doi.org/10.5194/amt-8-4699-2015, 2015.

Prinn, R., Cunnold, D., Simmonds, P., Alyea, F., Boldi, R., Crawford, A., Fraser, P., Gutzler, D., Hartley, D., Rosen, R., and Rasmussen, R.: Global average concentration and trend for hydroxyl radicals deduced from ALE/GAGE trichloroethane (methyl chloroform) data for 1978-1990, J. Geophys. Res., 97, 2445, https://doi.org/10.1029/91JD02755, 1992.

Pye, H. O. T., Liao, H., Wu, S., Mickley, L. J., Jacob, D. J., Henze, D. K., and Seinfeld, J. H.: Effect of changes in climate and emissions on future sulfate-nitrate-ammonium aerosol levels in the United States, J. Geophys. Res., 114, D01205, https://doi.org/10.1029/2008JD010701, 2009.

Pye, H. O. T., Chan, A. W. H., Barkley, M. P., and Seinfeld, J. H.: Global modeling of organic aerosol: the importance of reactive nitrogen $\left(\mathrm{NO}_{x}\right.$ and $\left.\mathrm{NO}_{3}\right)$, Atmos. Chem. Phys., 10, 1126111276, https://doi.org/10.5194/acp-10-11261-2010, 2010.

Ramanathan, V. and Carmichael, G.: Global and regional climate changes due to black carbon, Nat. Geosci., 1, 221-227, https://doi.org/10.1038/ngeo156, 2008.

Reynolds, R. W. and Reynolds, R. W.: A RealTime Global Sea Surface Temperature Analysis, J. Climate, 1, 75-87, https://doi.org/10.1175/15200442(1988)001<0075:ARTGSS>2.0.CO;2, 1988.

Ridley, D. A., Heald, C. L., and Ford, B.: North African dust export and deposition: A satellite and model perspective, J. Geophys. Res., 117, D02202, https://doi.org/10.1029/2011JD016794, 2012.

Schenkeveld, V. M. E., Jaross, G., Marchenko, S., Haffner, D., Kleipool, Q. L., Rozemeijer, N. C., Veefkind, J. P., 
and Levelt, P. F.: In-flight performance of the Ozone Monitoring Instrument, Atmos. Meas. Tech., 10, 1957-1986, https://doi.org/10.5194/amt-10-1957-2017, 2017.

Schepanski, K., Tegen, I., Laurent, B., Heinold, B., and Macke, A.: A new Saharan dust source activation frequency map derived from MSG-SEVIRI IR-channels, Geophys. Res. Lett., 34, L18803, https://doi.org/10.1029/2007GL030168, 2007.

Scollo, S., Kahn, R. A., Nelson, D. L., Coltelli, M., Diner, D. J., Garay, M. J., and Realmuto, V. J.: MISR observations of Etna volcanic plumes, J. Geophys. Res.-Atmos., 117, D06210, https://doi.org/10.1029/2011JD016625, 2012.

Shao, Y., Klose, M., and Wyrwoll, K.-H.: Recent global dust trend and connections to climate forcing, J. Geophys. Res.-Atmos., 118, 11107-11118, https://doi.org/10.1002/jgrd.50836, 2013.

Shi, W. and Wang, M.: Decadal changes of water properties in the Aral Sea observed by MODIS-Aqua, J. Geophys. Res.-Oceans, 120, 4687-4708, https://doi.org/10.1002/2015JC010937, 2015.

Shi, W., Wang, M., and Guo, W.: Long-term hydrological changes of the Aral Sea observed by satellites, J. Geophys. Res.-Oceans, 119, 3313-3326, https://doi.org/10.1002/2014JC009988, 2014.

Simon, H., Reff, A., Wells, B., Xing, J., and Frank, N.: Ozone Trends Across the United States over a Period of Decreasing $\mathrm{NO}_{x}$ and VOC Emissions, Environ. Sci. Technol., 49, 186-195, https://doi.org/10.1021/es504514z, 2015.

Spivak, L., Terechov, A., Vitkovskaya, I., Batyrbayeva, M., and Orlovsky, L.: Dynamics of Dust Transfer from the Desiccated Aral Sea Bottom Analysed by Remote Sensing, Springer, Berlin, Heidelberg, 97-106, 2012.

Spurr, R. J. D.: VLIDORT: A linearized pseudo-spherical vector discrete ordinate radiative transfer code for forward model and retrieval studies in multilayer multiple scattering media, J. Quant. Spectrosc. Ra., 102, 316-342, https://doi.org/10.1016/j.jqsrt.2006.05.005, 2006.

Stier, P., Seinfeld, J. H., Kinne, S., and Boucher, O.: Aerosol absorption and radiative forcing, Atmos. Chem. Phys., 7, 5237-5261, https://doi.org/10.5194/acp-7-5237-2007, 2007.

Storelvmo, T., Leirvik, T., Lohmann, U., Phillips, P. C. B., and Wild, M.: Disentangling greenhouse warming and aerosol cooling to reveal Earth's climate sensitivity, Nat. Geosci., 9, 286-289, https://doi.org/10.1038/ngeo2670, 2016.

Torres, O., Bhartia, P. K., Herman, J. R., Ahmad, Z., and Gleason, J.: Derivation of aerosol properties from satellite measurements of backscattered ultraviolet radiation: Theoretical basis, J. Geophys. Res., 103, 17099, https://doi.org/10.1029/98JD00900, 1998.

Torres, O., Tanskanen, A., Veihelmann, B., Ahn, C., Braak, R., Bhartia, P. K., Veefkind, P., and Levelt, P.: Aerosols and surface UV products from Ozone Monitoring Instrument observations: An overview, J. Geophys. Res., 112, D24S47, https://doi.org/10.1029/2007JD008809, 2007.

Torres, O., Chen, Z., Jethva, H., Ahn, C., Freitas, S. R., and Bhartia, P. K.: OMI and MODIS observations of the anomalous 2008-2009 Southern Hemisphere biomass burning seasons, Atmos. Chem. Phys., 10, 3505-3513, https://doi.org/10.5194/acp10-3505-2010, 2010.

Torres, O., Bhartia, P. K., Jethva, H., and Ahn, C.: Impact of the ozone monitoring instrument row anomaly on the long-term record of aerosol products, Atmos. Meas. Tech., 11, 2701-2715, https://doi.org/10.5194/amt-11-2701-2018, 2018.
Travis, K. R., Jacob, D. J., Fisher, J. A., Kim, P. S., Marais, E. A., Zhu, L., Yu, K., Miller, C. C., Yantosca, R. M., Sulprizio, M. P., Thompson, A. M., Wennberg, P. O., Crounse, J. D., St. Clair, J. M., Cohen, R. C., Laughner, J. L., Dibb, J. E., Hall, S. R., Ullmann, K., Wolfe, G. M., Pollack, I. B., Peischl, J., Neuman, J. A., and Zhou, X.: Why do models overestimate surface ozone in the Southeast United States?, Atmos. Chem. Phys., 16, 1356113577, https://doi.org/10.5194/acp-16-13561-2016, 2016.

Veefkind, J. P., Aben, I., McMullan, K., Förster, H., de Vries, J., Otter, G., Claas, J., Eskes, H. J., de Haan, J. F., Kleipool, Q., van Weele, M., Hasekamp, O., Hoogeveen, R., Landgraf, J., Snel, R., Tol, P., Ingmann, P., Voors, R., Kruizinga, B., Vink, R., Visser, H., and Levelt, P. F.: TROPOMI on the ESA Sentinel-5 Precursor: A GMES mission for global observations of the atmospheric composition for climate, air quality and ozone layer applications, Remote Sens. Environ., 120, 70-83, https://doi.org/10.1016/J.RSE.2011.09.027, 2012.

Wang, S., Zhang, Q., Martin, R. V, Philip, S., Liu, F., Li, M., Jiang, X., and He, K.: Satellite measurements oversee China's sulfur dioxide emission reductions from coal-fired power plants, Environ. Res. Lett., 10, 114015, https://doi.org/10.1088/17489326/10/11/114015, 2015.

Weatherhead, E. C., Reinsel, G. C., Tiao, G. C., Meng, X.-L., Choi, D., Cheang, W.-K., Keller, T., DeLuisi, J., Wuebbles, D. J., Kerr, J. B., Miller, A. J., Oltmans, S. J., and Frederick, J. E.: Factors affecting the detection of trends: Statistical considerations and applications to environmental data, J. Geophys. Res.-Atmos., 103, 17149-17161, https://doi.org/10.1029/98JD00995, 1998.

Weatherhead, E. C., Stevermer, A. J., and Schwartz, B. E.: Detecting environmental changes and trends, Phys. Chem. Earth, Parts A/B/C, 27, 399-403, https://doi.org/10.1016/S14747065(02)00019-0, 2002.

Wilks, D. S.: Statistical methods in the atmospheric sciences, Academic Press, 2011.

Xing, J., Mathur, R., Pleim, J., Hogrefe, C., Gan, C.-M., Wong, D. C., Wei, C., Gilliam, R., and Pouliot, G.: Observations and modeling of air quality trends over 1990-2010 across the Northern Hemisphere: China, the United States and Europe, Atmos. Chem. Phys., 15, 2723-2747, https://doi.org/10.5194/acp-152723-2015, 2015.

Zhang, L., Henze, D. K., Grell, G. A., Torres, O., Jethva, H., and Lamsal, L. N.: What factors control the trend of increasing AAOD over the United States in the last decade?, J. Geophys. Res.-Atmos., 122, 1797-1810, https://doi.org/10.1002/2016JD025472, 2017.

Zhang, Y., Wallace, J. M., Battisti, D. S., Zhang, Y., Wallace, J. M., and Battisti, D. S.: ENSO-like Interdecadal Variability: 190093, J. Climate, 10, 1004-1020, https://doi.org/10.1175/15200442(1997)010<1004:ELIV>2.0.CO;2, 1997.

Zhao, B., Wang, S. X., Liu, H., Xu, J. Y., Fu, K., Klimont, Z., Hao, J. M., He, K. B., Cofala, J., and Amann, M.: NOx emissions in China: historical trends and future perspectives, Atmos. Chem. Phys., 13, 9869-9897, https://doi.org/10.5194/acp13-9869-2013, 2013. 